\title{
Article \\ Development of Polyvinyl Alcohol/Kaolin Sponges Stimulated by Marjoram as Hemostatic, Antibacterial, and Antioxidant Dressings for Wound Healing Promotion
}

\author{
Tamer M. Tamer ${ }^{1, *,+}{ }^{+}$, Mosa H. Alsehli ${ }^{2}$, Ahmed M. Omer ${ }^{1}$, Tarek H. Afifi ${ }^{2}{ }^{\circledR}$, Maysa M. Sabet ${ }^{1}$, \\ Mohamed S. Mohy-Eldin ${ }^{1}$ (D) and Mohamed A. Hassan $3,4, *,+$ (D) \\ 1 Polymer Materials Research Department, Advanced Technology and New Materials Research \\ Institute (ATNMRI), City of Scientific Research and Technological Applications (SRTA-City), \\ New Borg El-Arab City, Alexandria 21934, Egypt; Ahmedomer_81@yahoo.com (A.M.O.); \\ Maysamohamed19@yahoo.com (M.M.S.); mohyeldinmohamed@gmail.com (M.S.M.-E.) \\ 2 Department of Chemistry, Taibah University, Madinah 30002, Saudi Arabia; \\ mosa_alsehli@hotmail.com (M.H.A.); afifith@yahoo.com (T.H.A.) \\ 3 Protein Research Department, Genetic Engineering and Biotechnology Research Institute (GEBRI), \\ City of Scientific Research and Technological Applications (SRTA-City), New Borg El-Arab City, \\ Alexandria 21934, Egypt \\ 4 University Medical Center Göttingen, Georg-August-University, 37073 Göttingen, Germany \\ * Correspondence: ttamer85@gmail.com (T.M.T.); madel@srtacity.sci.eg (M.A.H.); \\ Tel.: +20-34593414 (T.M.T.); +20-34593422 (M.A.H.) \\ + These authors equally contributed to this work.
}

Citation: Tamer, T.M.; Alsehli, M.H.; Omer, A.M.; Afifi, T.H.; Sabet, M.M.; Mohy-Eldin, M.S.; Hassan, M.A. Development of Polyvinyl Alcohol/Kaolin Sponges Stimulated by Marjoram as Hemostatic, Antibacterial, and Antioxidant Dressings for Wound Healing Promotion. Int. J. Mol. Sci. 2021, 22, 13050. https://doi.org/10.3390/ ijms 222313050

Academic Editor: Peter John Jervis

Received: 21 October 2021

Accepted: 24 November 2021

Published: 2 December 2021

Publisher's Note: MDPI stays neutral with regard to jurisdictional claims in published maps and institutional affiliations.

Copyright: () 2021 by the authors. Licensee MDPI, Basel, Switzerland. This article is an open access article distributed under the terms and conditions of the Creative Commons Attribution (CC BY) license (https:// creativecommons.org/licenses/by/ $4.0 /)$.
Abstract: The predominant impediments to cutaneous wound regeneration are hemorrhage and bacterial infections that lead to extensive inflammation with lethal impact. We thus developed a series of composite sponges based on polyvinyl alcohol (PVA) inspired by marjoram essential oil and kaolin (PVA/marjoram/kaolin), adopting a freeze-thaw method to treat irregular wounds by thwarting lethal bleeding and microbial infections. Microstructure analyses manifested three-dimensional interconnected porous structures for PVA/marjoram/kaolin. Additionally, upon increasing marjoram and kaolin concentrations, the pore diameters of the sponges significantly increased, recording a maximum of $34 \pm 5.8 \mu \mathrm{m}$ for PVA-M0.5-K0.1. Moreover, the porosity and degradation properties of $\mathrm{PVA} /$ marjoram/kaolin sponges were markedly enhanced compared with the PVA sponge with high swelling capacity. Furthermore, the PVA/marjoram/kaolin sponges exerted exceptional antibacterial performance against Escherichia coli and Bacillus cereus, along with remarkable antioxidant properties. Moreover, PVA/marjoram/kaolin sponges demonstrated significant thrombogenicity, developing high thrombus mass and hemocompatibility, in addition to their remarkable safety toward fibroblast cells. Notably, this is the first study to our knowledge investigating the effectiveness of marjoram in a polymeric carrier for prospective functioning as a wound dressing. Collectively, the findings suggest the prospective usage of the PVA-M0.5-K0.1 sponge in wound healing for hemorrhage and bacterial infection control.

Keywords: PVA; marjoram oil; kaolin; hemostatic dressing; antibacterial and antioxidant wound dressing

\section{Introduction}

Wound healing is an inherent rejuvenating reaction to skin damage. Essentially, the cutaneous healing process is orchestrated into four overlapping phases: hemostasis, inflammation, proliferation, and tissue remodeling [1,2].

Instantly following a skin injury, avascular constriction and blood clotting cascade preclude the hemorrhage and infiltration of microorganisms. Furthermore, blood clots also serve as a reservoir for growth factors and cytokines as well as a scaffold for immigrant cells 
recruited for wound recovery and tissue regeneration [3,4]. On the other hand, bleeding has been the predominant cause of mortality in civilian and military communities over past decades. In trauma patients, instant hemorrhage management through blood clotting intervention is imperative since most deaths emerge within the first hour following severe trauma $[5,6]$. Moreover, uncontrolled bleeding impedes wound healing and provokes significant consequences, including severe inflammation and microbial infections of the wound [7].

The blood clotting pathway is coordinated in three sequential phases: (I) initiation, which involves the production of thrombin, (II) amplification, which is characterized by activation and aggregation of platelets; and (II) proliferation, which is characterized by the development of fibrin alongside stability of platelet clot. Most applied hemostatic agents play a crucial role by enhancing platelet aggregation and coagulation within the amplification and proliferation phases [8].

A hemostatic agent should encounter specific vital characteristics, including ease of use, cost-effectiveness, hemocompatibility, cytocompatibility, and intrinsic biodegradability [9]. Injectable hydrogels have revealed good healing with hemostatic properties [10]; nevertheless, they typically have insufficient mechanical features, curtailing their implementation as hemostatic materials [11]. Furthermore, such injectable hydrogels might incite adverse complications for patients, aggravating the treated wound since it is painful either to change or remove them, particularly from profound injuries [12]. Thus, developing porous sponges with hemostatic, antibacterial, and antioxidant performances is advantageous because of their distinct three-dimensional structures, which enable them to have mechanical stability. Moreover, it is worth pointing out that the three-dimensional structure fortifies the adhesion and proliferation of cells recruited for wound healing [9].

Polyvinyl alcohol (PVA)-based porous sponges have demonstrated outstanding mechanical properties and remarkable biocompatibility [13]. Physical cross-linking could be adopted to formulate PVA sponges to evade the utilization of chemical cross-linking solvents, which might be hazardous for biomedical applications. Therefore, sequential freeze-thawing could cross-link PVA-based sponges, which could develop crystalline clusters as a cross-linking point $[14,15]$. Given that the PVA sponge lacks hemostatic and antibacterial capacities, it is thus indispensable to adapt the PVA sponge by incorporating a hemostatic agent, such as kaolin to stimulate blood cells and platelet accumulation, and another bioactive compound (marjoram essential oil) to endow the sponge with antibacterial and antioxidant capacities to frustrate the inflammation in the wound bed.

Kaolin has thus been identified as one of the significant hemostatic agents, which could substantially promote blood coagulation [16]. Kaolin, often known as China clay, principally comprises kaolinite and aluminium silicate [16]. Given that negative charges on the kaolin surface could substantially promote blood coagulation, kaolin was successfully implemented as active material in surgical hemostasis. Furthermore, kaolin could induce factor XII and platelets, further initiating the blood clotting cascade [17].

Marjoram (Origanum majorana L.) is one of the promising essential oil candidates for several applications. It is an herbaceous and perennial plant broadly cultivated in various areas of the globe and could be used for traditional medicine [18]. In addition, previous studies have evidenced marjoram's antibacterial, antioxidant, anti-inflammatory, and anticancer properties [19]. The major constituents of marjoram essential oil are terpinen4 -ol (which accounts for more than $20 \%$ of the total), (+)-cis-sabinene hydrate (3-18\%), $\gamma$-terpinene and terpinolene, thymol, and carvacrol [20]. In addition, the high antioxidant activity of oil derived from marjoram accounted for the predominance of phenolic acids and terpenoids [21].

We presumed that the synergistic effect of the sponge composite based on PVA, marjoram essential oil, and kaolin could effectively frustrate the hemorrhage and the microbial infections of injury alongside the competency of PVA to seal the wound, which could significantly accelerate the action of the devised sponge. We thus fabricated a series of PVA/marjoram/kaolin porous sponge composites as hemostatic and antibacterial 
wound dressings. The designed sponges were characterized to determine their physical and chemical attributes in order to explore the extent to which these sponges correspond with the paramount traits of the ideal wound dressing. Additionally, the antibacterial and antioxidant activities and the hemostatic capability of the developed sponges were assessed. Moreover, the cytotoxicity of the sponges was studied in relation to the human dermal fibroblast. The findings of these in vitro investigations will ascertain the favorable sponge, which will require further in vitro and in vivo investigations to fully validate its application as a promising hemostatic and antibacterial dressing.

\section{Results and Discussion}

\subsection{Development of PVA/Marjoram/Kaolin Sponges}

In our previous investigations, we manifested the potency of hemostatic and antibacterial performances of PVA/kaolin, which were reinforced by penicillin-streptomycin [22]. However, the antibacterial activities of these sponges substantially depend on the presence of antibiotics that might be frustrated by the emergence of resistant bacteria. Furthermore, the antioxidant activity of these sponges has not been reported.

Due to these shortcomings, we aspired in this study to devise non-antibiotic sponges for further implementation in the wound healing process. Given the particular structure and tunable traits of PVA, it is predominantly recruited for hydrogel development by cyclical freezing-thawing to develop crystalline clusters alongside its competency acting as a carrier of drugs [23]. As portrayed in Figure 1, we formulated new crosslinked sponges using PVA inspired by marjoram extract and kaolin employing a freezing-thawing approach. Moreover, due to the antibacterial, antioxidant, and hemostatic deficiencies of PVA, marjoram extract and kaolin were incorporated into the designed sponges. After freezing-thawing, PVA, marjoram extract, and kaolin, in addition to high water molecules, were entrapped and entangled into the physically crosslinked three-dimensional network of sponges. The developed sponges with various concentrations of marjoram extract were labelled as PVA-M0.1, PVA-M0.25, and PVA-M0.5, while those boosted by marjoram extract and kaolin were denominated as PVA-M0.5-K0.1, PVA-M0.5-K0.25, and PVA-M0.5-K0.5. 


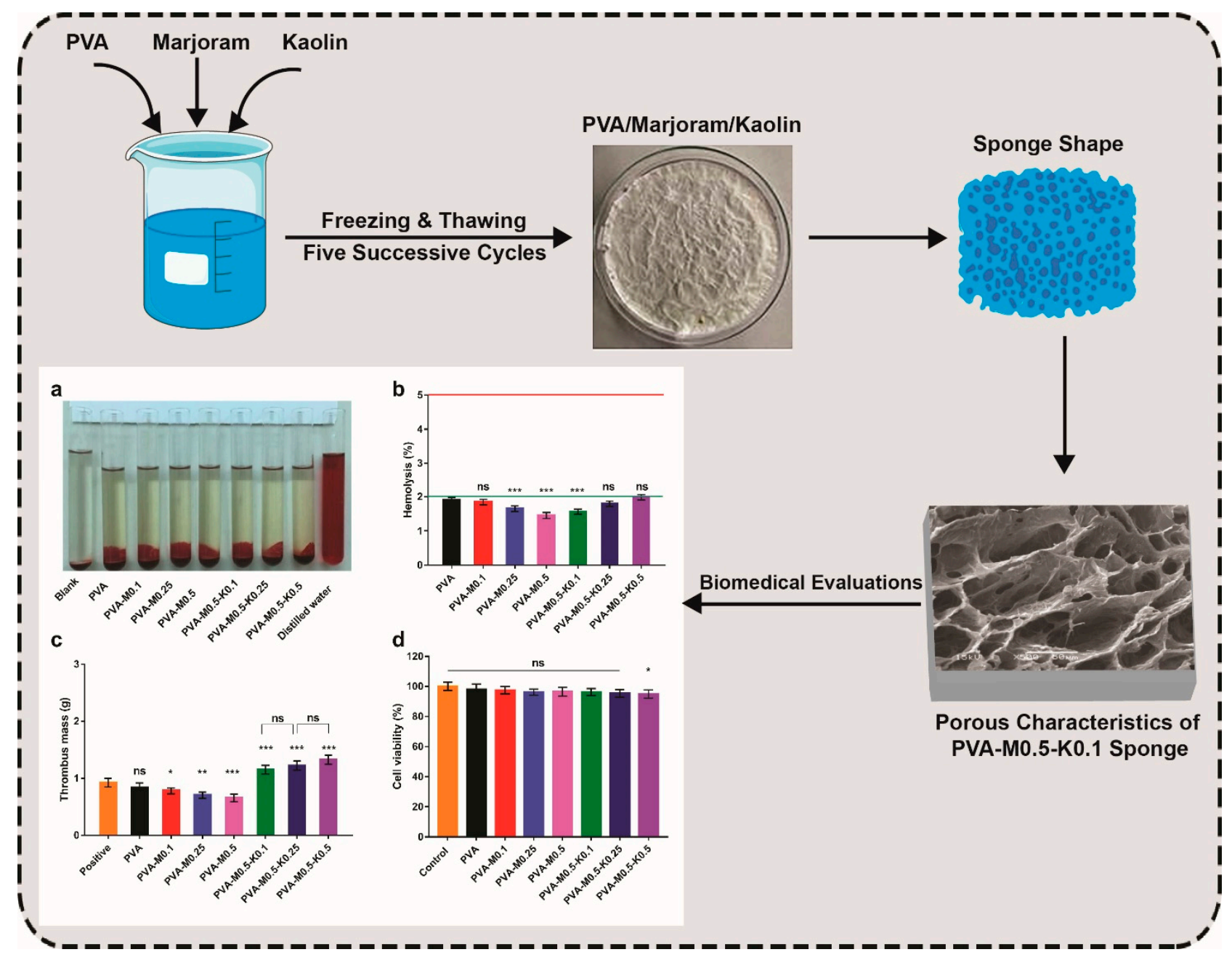

Figure 1. Schematic illustration of the fabrication and biomedical evaluations of hemostatic and antibacterial PVA/marjoram/kaolin sponges. $\quad((\mathbf{a}-\mathbf{d})$ in the scheme depict some of the biomedical evaluations performed for $\mathrm{PVA} /$ marjoram/kaolin composite sponges, including biocompatibility and thrombogenicity with statistical analysis (*** $p<0.001,{ }^{* *} p<0.01,{ }^{*} p<0.05$, and (ns) points to a non-significant difference).

\subsection{Characterization of PVA/Marjoram/Kaolin Sponges \\ 2.2.1. FT-IR Analysis}

As illustrated in Figure 2, the structures of the PVA sponge and the alterations of PVA composite sponges, including marjoram oil and kaolin with different contents, were studied by means of FT-IR. The appearance of characteristic bands at $3387 \mathrm{~cm}^{-1}$ is assigned to $-\mathrm{OH}$ on hydrogen bonds between - $\mathrm{OH}$ groups among PVA chains, bestowing the hydrophilic strengths to the PVA sponge [24]. The methyl groups' asymmetrical and symmetrical C-H stretching vibration modes could be perceived in the PVA spectrum at $2926 \mathrm{~cm}^{-1}$. Moreover, the band at $2845 \mathrm{~cm}^{-1}$ corresponds to a methylene vibration band, whereas the distinct band at $1710 \mathrm{~cm}^{-1}$ is imputed to the stretching vibration band of the remaining acetyl carbonyl groups. The appearance of the band at $1450 \mathrm{~cm}^{-1}$ is attributed to asymmetrical and symmetrical $\mathrm{CH}$ bending vibrations of methyl groups [24].

Furthermore, a prominent band at $1118 \mathrm{~cm}^{-1}$ is the main indicator of the PVA structure [25], while a band at $1085 \mathrm{~cm}^{-1}$ corresponds to C-O-C. Incorporation of marjoram into PVA generated a new band at $1660 \mathrm{~cm}^{-1}$, which interacted with the stretching vibration band of the remaining acetyl carbonyl groups in the PVA. Evidently, this band turned out to be clearer at high concentrations of marjoram. On the other hand, the addition of kaolin to PVA/marjoram sponges led to the appearance of peaks at 920 to $940 \mathrm{~cm}^{-1}$ related to 
Al-OH vibration. Additionally, the bands at 530 and $789 \mathrm{~cm}^{-1}$ correspond to the Si-O-Al bond vibration band.

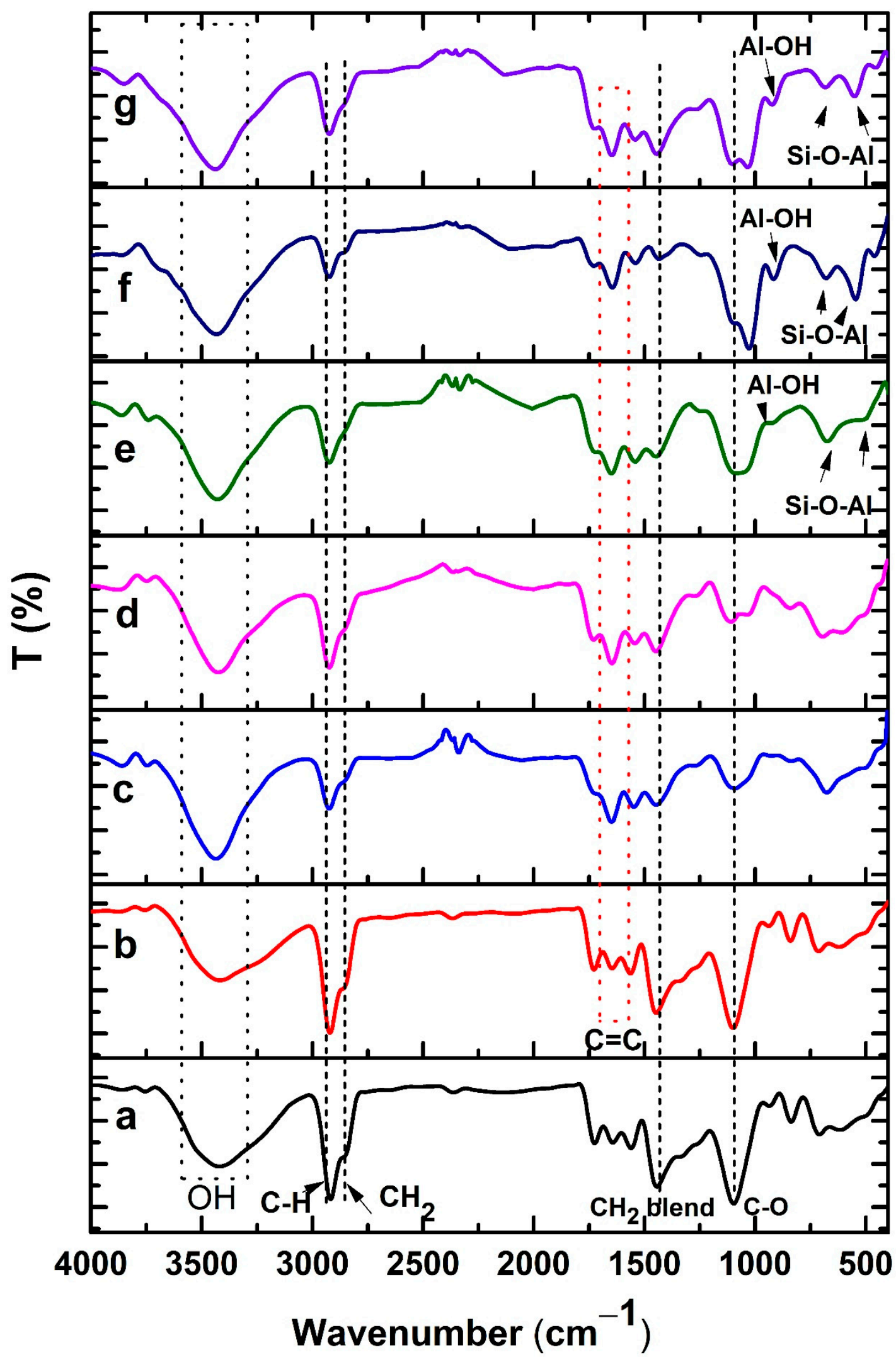

Figure 2. FT-IR spectra of (a) PVA, (b) PVA-M0.1, (c) PVA-M0.25, (d) PVA-M0.5, (e) PVA-M0.5-K0.1, (f) PVA-M0.5-K0.25, and (g) PVA-M0.5-K0.5 composite sponges. 


\subsubsection{SEM Analysis}

Microstructures of the synthesized sponges were probed by means of SEM. The morphological surface of the pure PVA sponges exhibited fewer pores than the PVA sponge composites. However, the PVA sponge composites amalgamated with various ratios of either marjoram (PVA/marjoram) or marjoram and kaolin (PVA/marjoram/kaolin) revealed three-dimensional structures interconnected with varied pore sizes in asymmetric arrangements as illustrated in Figure 3a-g. Furthermore, cross-sectional micrographs of the PVA/marjoram and PVA/marjoram/kaolin sponges exposed asymmetric neat structures with prominent three-dimensional interconnected networks as portrayed in Figure $4 \mathrm{a}-\mathrm{g}$. Furthermore, the sponge composites showed porous sponge layers with evident lamellar structures comparable to previously applied PVA sponge composites in wound healing with remarkable performances $[13,26]$. The sponge with a dense structure, on the other hand, is not favorable for hemostatic wound dressings, which necessitates high conductivity to the wound for absorbing wound surplus exudate and interacting with blood to enhance the hemostatic reaction [26,27].
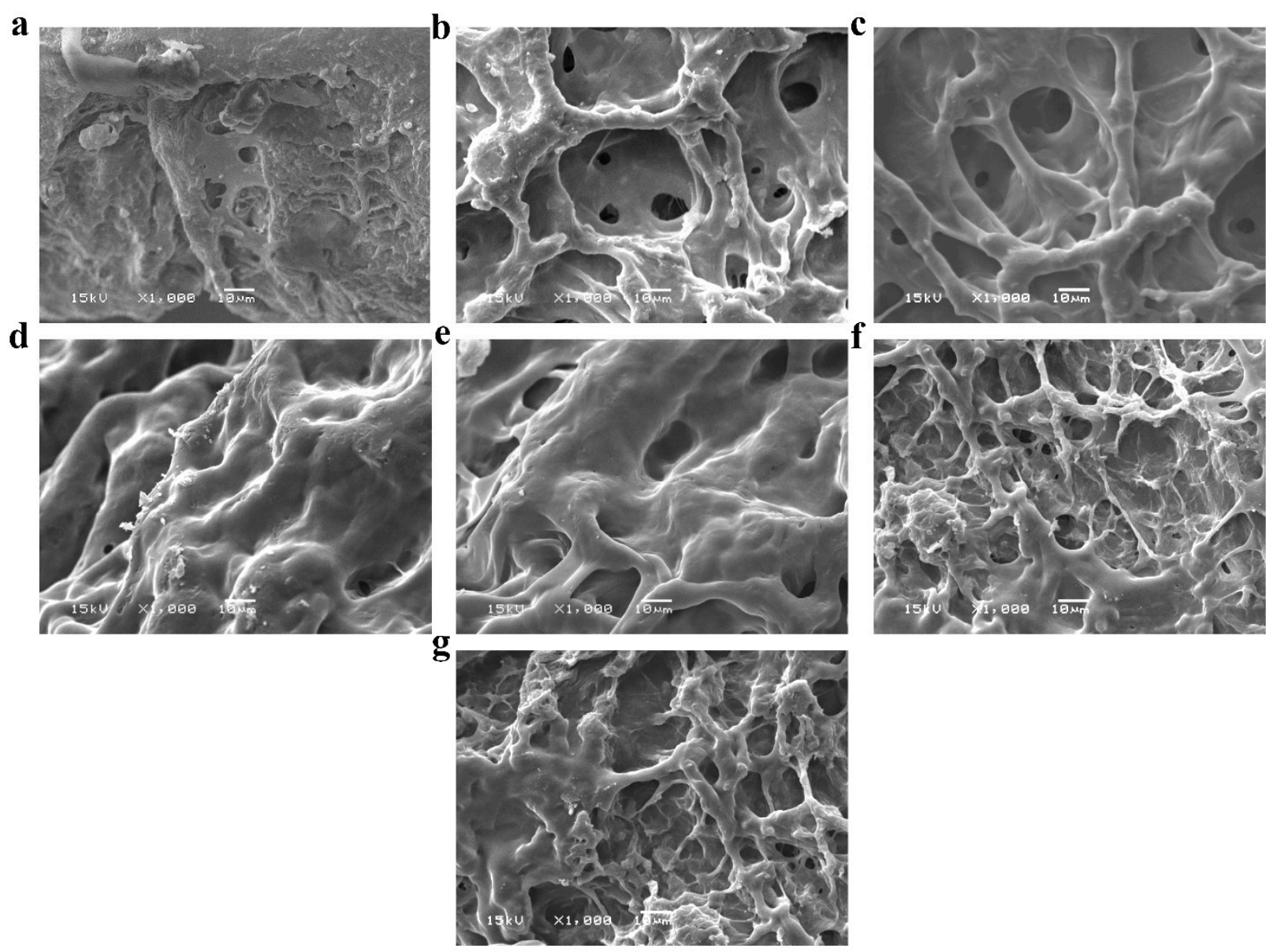

Figure 3. SEM images reveal surface morphologies of (a) PVA, (b) PVA-M0.1, (c) PVA-M0.25, (d) PVA-M0.5, (e) PVA-M0.5K0.1, (f) PVA-M0.5-K0.25, and (g) PVA-M0.5-K0.5 composite sponges at a magnification of $1000 \times$.

Moreover, antibacterial and antioxidant wound dressings should firmly seal the wound to stall the bacterial invasion and mitigate the free radicals generated during the wound healing process [28]. Given these requisites, the development of highly porous sponges is indispensable to promote the attachment and proliferation of keratinocytes and fibroblasts during epithelialization, thereby stimulating angiogenesis at the wound bed [29]. Besides, such sponges prevent the dehydration of the wound, permitting the 
exchange of fluids and gases toward the wound and furnishing the corresponding cells with nutrients required for its propagation [27].

From the data in Figure $4 a^{\prime}-d^{\prime}$, it can be perceived that the extent of pore sizes of the developed sponges increased with the rise of marjoram ratios, recording $12.9 \pm 3.4 \mu \mathrm{m}$, $21.2 \pm 6 \mu \mathrm{m}, 22.7 \pm 4.7 \mu \mathrm{m}, 24.6 \pm 5.2 \mu \mathrm{m}$ for PVA, PVA-M0.1, PVA-M0.25, and PVAM0.5, respectively. These findings are most likely due to the lessening of molecular crystallizations of PVA, which act on the cross-linking sites of marjoram extract, leading to the diminution in crosslinking density in the case of PVA/marjoram sponges [30,31]. Furthermore, the amalgamation of various kaolin concentrations into PVA/marjoram augmented the pore sizes, reporting $34 \pm 5.8 \mu \mathrm{m}, 29.5 \pm 7.1 \mu \mathrm{m}, 25.1 \pm 4.9 \mu \mathrm{m}$ for PVAM0.5-K0.1, PVA-M0.5-K0.25, and PVA-M0.5-K0.5, respectively, as presented in Figure 4e', $\mathrm{f}^{\prime}$. As delineated in Figure 4h, the maximum pore size was determined for PVA-M0.5-K0.1, while the increase in kaolin ratios lowered the pore size. This might be attributed to the aggregation of kaolin with marjoram extract as a consequence of the emulsification of the marjoram oil.
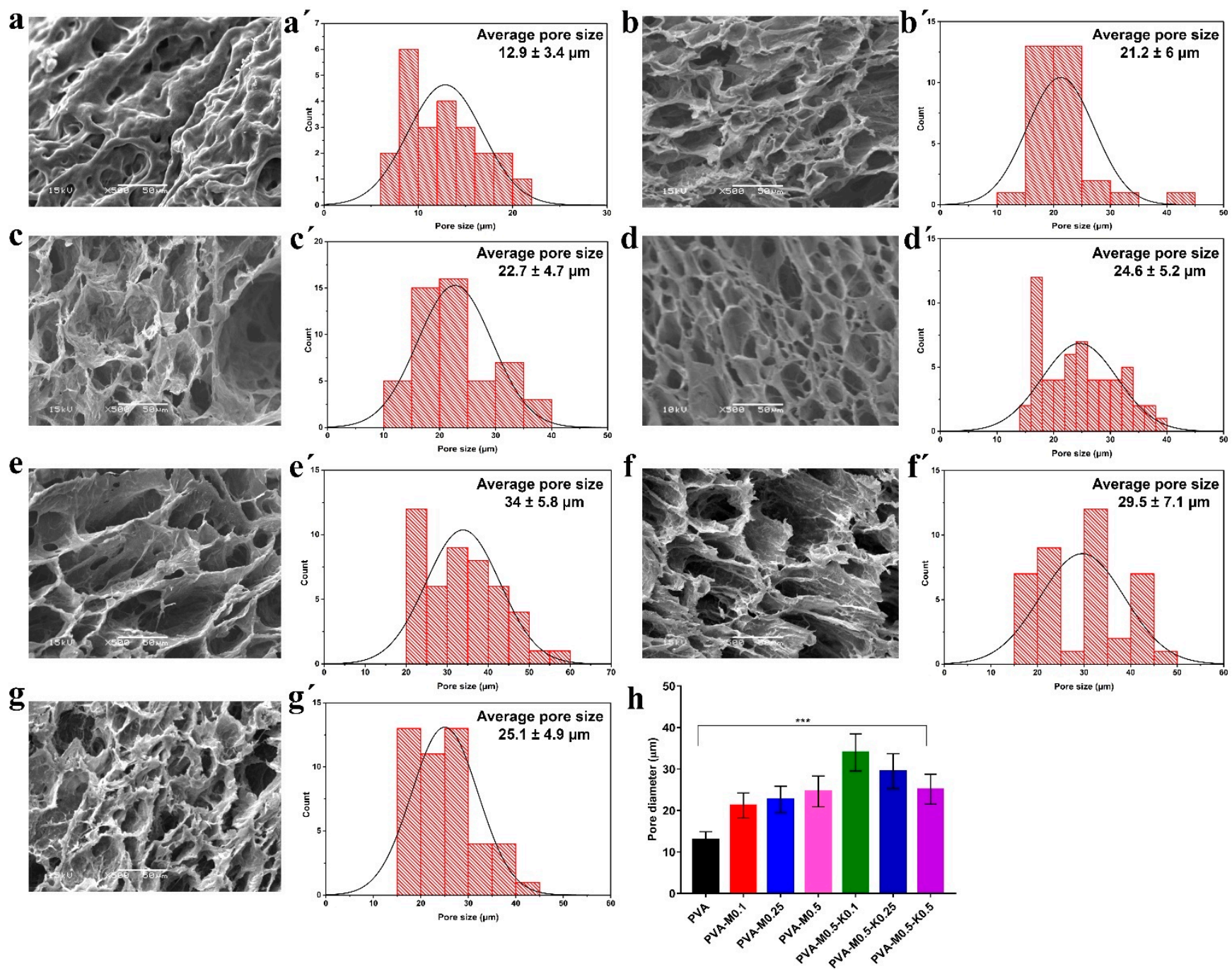

Figure 4. SEM images show cross-sectional and porous structures (a) PVA, (b) PVA-M0.1, (c) PVA-M0.25, (d) PVA-M0.5, (e) PVA-M0.5-K0.1, (f) PVA-M0.5-K0.25, and (g) PVA-M0.5-K0.5 composite sponges at a magnification of 500 $\times$. (a'- $\left.\mathbf{g}^{\prime}\right)$ illustrates the pore size distribution of PVA, PVA-M0.1, PVA-M0.25, PVA-M0.5, PVA-M0.5-K0.1, PVA-M0.5-K0.25, and PVA-M0.5-K0.5 composite sponges, respectively. (h) indicates the size of the average pores of PVA, PVA/marjoram, and $\mathrm{PVA} /$ marjoram/kaolin sponges. Results are presented as means $\pm \mathrm{SD}\left({ }^{* * *} p<0.001\right)$. 
These findings are consistent with those of earlier studies [31], which demonstrated the outstanding impacts of the wound dressings with pore sizes in a range of 19.5-36.7 $\mu \mathrm{m}$. Moreover, previously fabricated Poly(ionic liquid)/PVA hydrogels based on PVA with pore sizes ranging from 10 to $30 \mu \mathrm{m}$ exhibited an influential role during the wound healing of rats [13]. Furthermore, previous reports showed that the wound dressings with pore sizes ranging from 20 to $125 \mu \mathrm{m}$ had a decisive function in furnishing the dermal cells with oxygen and necessary nourishments, thereby ameliorating the regeneration of skin tissues [32]. Moreover, it has been reported that the measurements of significant human cells extend over a range from 2 to $120 \mu \mathrm{m}$ [12]. Collectively, the PVA/marjoram and $\mathrm{PVA} / \mathrm{marjoram} /$ kaolin with pore sizes in the range of 21-34 $\mu \mathrm{m}$ could be encouraging sponge composites for further implementation as wound dressings.

\subsubsection{TGA}

The thermal degradation behaviors of PVA and PVA/marjoram/kaolin sponges were investigated using TGA as shown in Figure 5. The figure charts represent several degradation steps of sponge composites. The initial stage started at ambient temperature, indicating the loss of piping water moisture content. Specifically, PVA neat sponges exhibited weight losses of $6.55 \%$ at $98.8^{\circ} \mathrm{C}$, PVA-M0.1 lost $6.76 \%$ at $73.84{ }^{\circ} \mathrm{C}$, PVA-M0.25 lost $6.52 \%$ at $71.44{ }^{\circ} \mathrm{C}$, PVA-M0.5 lost $6.16 \%$ at $67.67{ }^{\circ} \mathrm{C}$, PVA-M0.5-K0.1 lost $5.98 \%$ at $67.5^{\circ} \mathrm{C}$, while PVA-M0.5-K0.25 and PVA-M0.5-K0.5 weight losses were $4.64 \%$ and $4.86 \%$, respectively at $67.9^{\circ} \mathrm{C}$. Marjoram oil and kaolin had significant effects on the moisture contents of sponges, in which increase in marjoram or kaolin concentrations exhibited a significant decrease in the trapped solvent or water molecules. This might be attributed to the hydrophobic nature of marjoram oil, whereas in the case of kaolin, it could be explained by a decrease in the PVA content in the composite ratio, in which hydroxyl groups of PVA have a significant role in trapping moisture content. The combination of marjoram oil in the blend sponges resulted in new degradation characters perceived in peak between $109-200{ }^{\circ} \mathrm{C}$ with a magnitude weight loss of $3.89 \%$ for PVA-M0.1, 7.56\% for PVA-M0.25 and 9.4\% for PVA-M0.5. This could be attributed to the loss of volatile components of marjoram oil. It could also be recognized that this peak was absent in the sponge containing kaolin, which may be explained by the role of kaolin for stabilizing marjoram oil in the blend structure. Second weight loss for PVA sponges was observed from $226^{\circ} \mathrm{C}$ to $314{ }^{\circ} \mathrm{C}$ with a weight loss of $62.5 \%$ corresponding to thermal decomposition of PVA backbone and eliminated water and carbon dioxide. The weight loss of this degradation stage was decreased by the addition of marjoram and more significantly by adding kaolin. Formulation of PVA blends with marjoram and kaolin stimulated the formations of the internal micro pore that can act as an interior atmosphere and trapped degraded byproduct carbon dioxide gases. The third degradation stage until $600{ }^{\circ} \mathrm{C}$ could be ascribed to the decomposition of organic residues. The remaining weight over $600{ }^{\circ} \mathrm{C}$ refers to the inorganic remains of kaolin, which did not degrade at this temperature. 


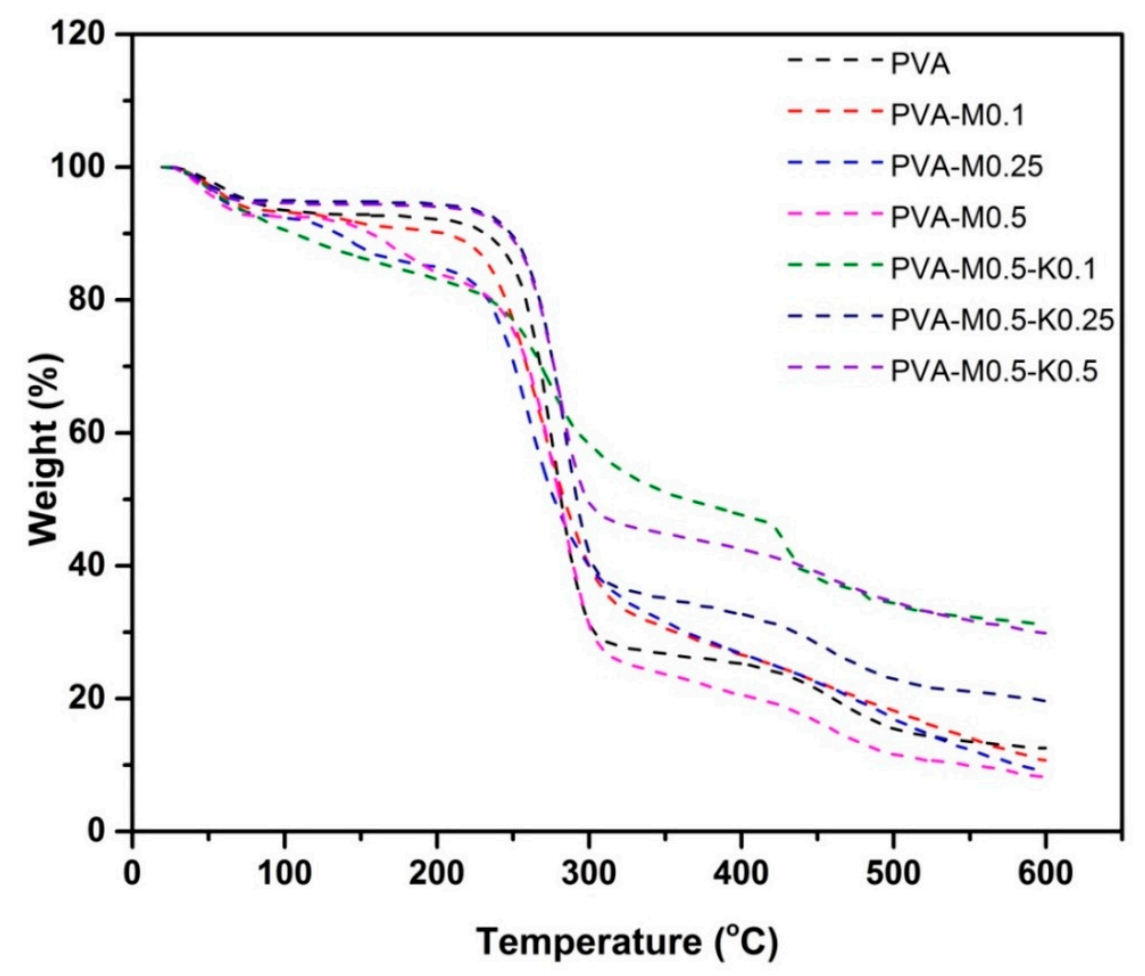

Figure 5. TGA charts of PVA, PVA/marjoram, and PVA/marjoram/kaolin composite sponges.

2.2.4. Gel Fraction, Swelling Profile, Hydrodegradation In Vitro, and Porosity Analyses

Gel fraction properties of PVA/marjoram and PVA/marjoram/kaolin sponges were inspected to explore the influence of marjoram oil and marjoram alongside kaolin particles on gel formation, respectively. Figure 6a demonstrates that the introduction of marjoram oil into the PVA significantly dropped the gel fraction percentages, recording $87.5 \pm 3.4 \%$, $80.3 \pm 2.4 \%, 79.2 \pm 2.9 \%$, and $76.8 \pm 2.5 \%$ for PVA, PVA-M0.1, PVA-M0.25, and PVA-M0.5, respectively. However, the results showed no significant differences correlated with the increase of marjoram ratios. On the other hand, the gel fraction ratios were insignificantly lowered for the PVA-M0.5-K0.1 (74.9 $\pm 2.1 \%)$ compared to the entire PVA/marjoram groups. At the same time, the additional growth in kaolin concentrations significantly amplified the gel fraction ratios, reporting $82 \pm 3.8 \%$ and $83 \pm 2.9 \%$ for PVA-M0.5-K0.25, PVA-M0.5-K0.5, respectively. Therefore, it seems possible that these results are due to the manipulation influence of marjoram and kaolin particles on the structure of PVA. Additionally, these outcomes indicate that incorporating marjoram and kaolin into the PVA weakened the crosslinking density, which might further enhance the swelling behavior of $\mathrm{PVA} / \mathrm{marjoram} /$ kaolin dressings [33]. It could thus reinforce the absorption aptitude of excess wound exudates by these respective sponges, hampering adverse complications.

The swelling capability of hemostatic dressings acts as a key factor for hemostasis and wound healing downstream by governing the bleeding, drugs' release, degradation, and biological fluid absorption [34]. Accordingly, the 3-dimensional polymeric structures alongside the hydrophilic groups associated with the backbone of polymer chains improve the capacity of sponges to absorb great amounts of water without disintegration [35]. Therefore, the in vitro swelling characteristics of the developed sponges were analyzed, as displayed in Figure $6 \mathrm{~b}$. Swelling performances showed significant statistical differences $(p<0.001)$ in the swelling percentages for the entire sponges in relation to the PVA sponge. Furthermore, upon immersing the sponges in the water, quick swelling ratios were recorded for PVA/marjoram and PVA/marjoram/kaolin sponges with regard to the PVA. This is a very important property for hemostatic dressings in order to concentrate blood clotting determinants, thereby stimulating hemostasis [36]. Specifically, in the case of PVA/marjoram, the greatest water retention of $310 \pm 9 \%$ was reported for PVA-M0.1 
after $1.5 \mathrm{~h}$ among the other respective sponges. Furthermore, the increase in the ratio of marjoram oils resulted in significant reductions in the swelling manners, reporting $238 \pm 11 \%$ and $236 \pm 8 \%$ for PVA-M0.25, and PVA-M0.5 groups, respectively. This could be linked to the hydrophobic effect of oil ingredients [37].

On the other hand, the addition of kaolin particles at the lowest concretion for the PVAM0.5-K0.1 sponge slightly influenced the swelling capacity, recording $233 \pm 5 \%$. Moreover, the statistical analyses exposed no significant variances in the PVA-M0.5-K0.1 sponge compared with the PVA-M0.25 and PVA-M0.5 groups. Nevertheless, the swelling ratios significantly decreased with the growth in kaolin levels. These findings could be attributed to the difference in the pore sizes, consistent with the data obtained from SEM analyses. Furthermore, the swelling ratios of the whole sponges levelled off after $4 \mathrm{~h}$, accomplishing an equilibrium state. Additionally, the PVA-M0.1 group achieved the highest swelling ratio of $315 \pm 12 \%$ after $4 \mathrm{~h}$ among the PVA/marjoram groups, while the greatest swelling ratio of $239 \pm 7 \%$ was found for the PVA-M0.5-K0.1 sponge among the PVA/marjoram/kaolin sponges. Additionally, the graph shows that the similar results remained steady after $8 \mathrm{~h}$. Previous studies reported the promotion of wound healing in vivo by applying wound dressings formulated on the basis of PVA and other biopolymers with different swelling percentages of $20 \%, 102 \%$ and $130 \%$ [13,38,39], highlighting the potential use of the PVA-M0.5-K0.1 sponge to ameliorate wound recovery.

The in vitro degradation of the PVA/marjoram and PVA/marjoram/kaolin sponges was studied by submerging them in PBS at $37^{\circ} \mathrm{C}$ for predetermined times. As can be seen in Figure $6 \mathrm{c}$, after $72 \mathrm{~h}$ of incubation, the PVA/marjoram sponges showed detectable weight losses of $23.7 \pm 0.9 \%, 26.2 \pm 1 \%$, and $28.5 \pm 0.6 \%$ for PVA-M0.1, PVA-M0.25, and PVA-M0.5, respectively. In contrast, the PVA group exhibited a weight loss of $20.5 \pm 0.7 \%$. These outcomes imply that the addition of marjoram oil promoted the degradation rate of sponges. On the other hand, the incorporation of kaolin alongside marjoram oil reduced the weight loss ratios, reporting $28.2 \pm 0.8 \%, 23 \% \pm 1$, and $21.3 \pm 0.8 \%$ for PVA-M0.5-K0.1, PVA-M0.5-K0.25, and PVA-M0.5-K0.5, respectively. This could be related to the aggregation of kaolin and marjoram, which could be perceived with the high concentration of kaolin. It is presumed that the in vitro degradation could impact the drug release represented by marjoram in this study, which is consistent with earlier studies [40,41]; thus, PVA-M0.5-K0.1 could be considered as the ideal wound dressing.

In aiming to appraise the water holding capacity of PVA/marjoram and PVA/marjoram/ kaolin sponges, the porosity was tested. Figure $6 \mathrm{~d}$ delineates the positive influence of marjoram oil on the porosity ratios for PVA/marjoram groups. The porosity for the PVA was $54.2 \pm 2.4 \%$, whereas PVA-M0.1, PVA-M0.25, and PVA-M0.5 reported porosities of $59.1 \pm 2 \%, 65.8 \pm 3.6 \%$, and $74.4 \pm 2.1 \%$, respectively. This might be a result of the distortion impact of the marjoram oil on the internal structure of the polymer. Nonetheless, the introduction of kaolin particles into PVA-M0.5 lessened the porosity, and this decrease is correlated with the growth of the supplemented kaolin ratio. For PVA/marjoram/kaolin sponges, the porosity was determined to be $62.8 \pm 3.9 \%, 60.5 \pm 2.4 \%$, and $55.8 \pm 3.1 \%$ for PVA-M0.5-K0.1, PVA-M0.5-K0.25, and PVA-M0.5-K0.5, in respective order. These findings are in line with those of previous studies [42]. This performance might be related to the frequency of kaolin particles within the pores of sponges consuming some hydrogen bonds. Thus, the sponges turned out to be more compressed, and this obstructs the utilization of previously available pores [22]. The high porosity and water uptake competency of wound dressings are vital features for precluding microorganism invasion, expanding drug loading, and promoting dermal cell adherence and propagation. It could therefore ameliorate wound healing through preventing the prolongation of the inflammation phase.

In summary, swelling capacity, porosity, and biodegradation characteristics point to PVA-M0.5-K0.1 among the tested sponges for wound dressing applications. 


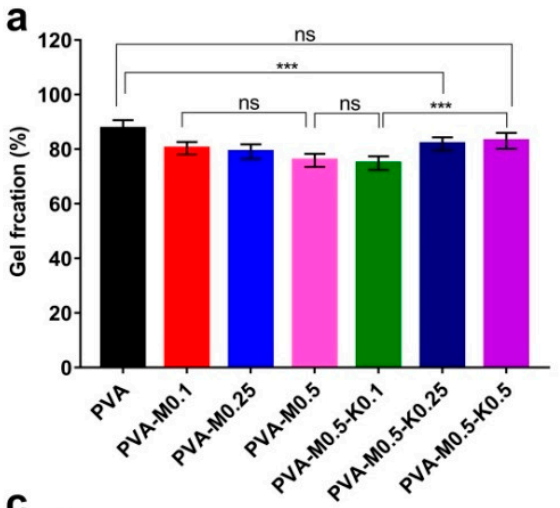

C

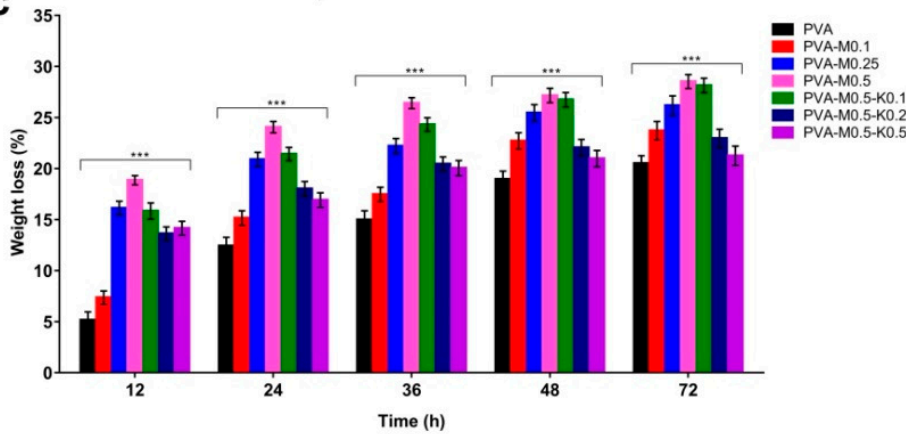

b
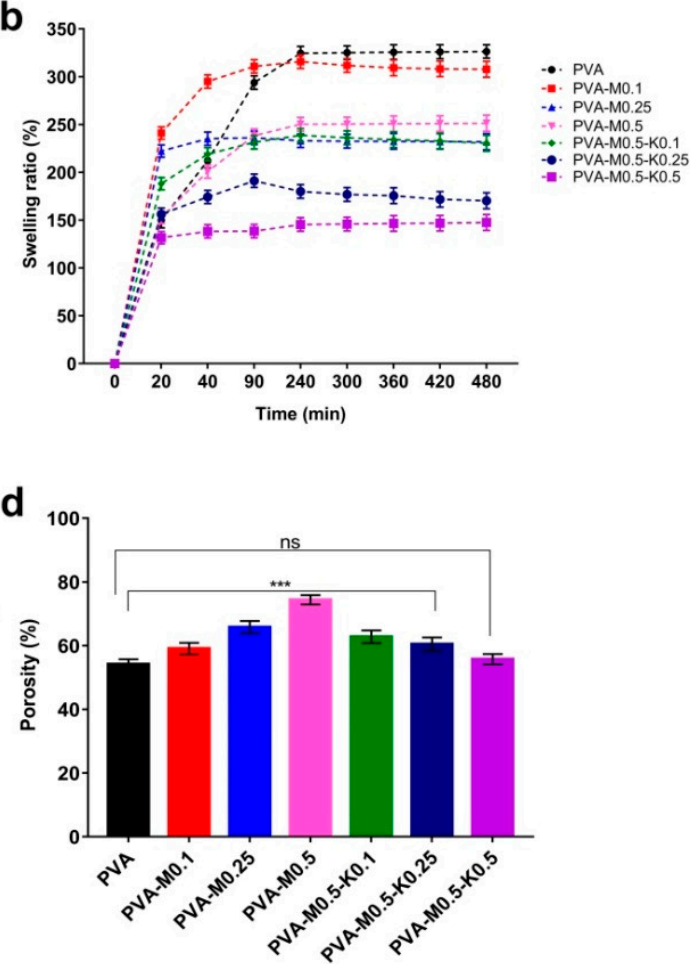

Figure 6. (a) Gel fractions, (b) Swelling characteristics, (c) In vitro weight loss, and (d) Porosity evaluations PVA/marjoram, and PVA/marjoram/kaolin composite sponges compared with the pure PVA sponge. Results are stated as means \pm SD $(n=5)(* * *<0.001$, and (ns) points to non-significant difference).

\subsection{Antibacterial Evaluation}

The antibacterial activity of wound dressing is paramount to preclude the growth of pathogenic microorganisms on the wound bed and even on the surface of the wound dressing itself, which retards the rejuvenation of skin tissues and might incite tissue maceration $[39,43-45]$. To this end, we bolstered the devised sponges with marjoram oil as one of the natural antibacterial products as an alternative to conventional antibiotics to prevent the emergence of multi-drug resistant bacteria [21]. The antibacterial performances of PVA/marjoram and PVA/marjoram/kaolin sponges against B. cereus and E. coli were estimated by the growth turbidity method, as shown in Figure 7a. A significant positive correlation between the antibacterial capacity of PVA/marjoram sponges and the increase in the marjoram ratios is discernible. Specifically, the pure PVA sponges revealed no activity with regard to the tested bacteria. Remarkably, the addition of marjoram bestowed the antibacterial potency on the PVA-M0.1, PVA-M0.25, and PVA-M0.5 sponges, recording $31 \%$, $65 \%$, and $85 \%$ with regard to B. cereus, respectively. Moreover, PVA-M0.1, PVA-M0.25, and PVA-M0.5 sponges exerted growth inhibitions of $63 \%, 87 \%$, and $90 \%$ in relation to E. coli, respectively. The variations in antibacterial capacity could be ascribed to the dissimilarity of cell walls for Gram-positive and Gram-negative bacteria.

The introduction of kaolin into the sponges in terms of PVA/marjoram/kaolin sponges showed no substantial differences in antibacterial activity for the PVA-M0.5-K0.1 and PVAM0.5-K0.25 groups compared with the PVA-M0.5 group. By contrast, the antibacterial activity of the PVA-M0.5-K0.5 group was significantly diminished. This phenomenon could stem from the aggregation of kaolin with marjoram, hampering the release of marjoram oil into the medium.

The antibacterial features of PVA/marjoram and PVA/marjoram/kaolin sponges were further investigated using a colony-forming unit. As illustrated in Figure $7 \mathrm{~b}$, comparable trends to the previous results could be perceived. Significantly, PVA-M0.5 sponges could inhibit $95 \%$ and $97 \%$ of B. cereus and E. coli, respectively. Furthermore, the antibacterial 
behaviors of the PVA-M0.5-K0.1 group revealed no statistical differences in comparison with the PVA-M0.5 group, reporting growth inhibition ratios of $95 \%$ and $97 \%$ toward $B$. cereus and E. coli, respectively. In contrast to these findings, the inhibition ratios of the examined bacteria significantly lessened for PVA-M0.5-K0.25 and PVA-M0.5-K0.5 sponges. The variance of these results compared to the previous approach for PVA-M0.5-K0.25 could be explained by the inevitable measurement of viable and dead bacterial cells by the spectrophotometer in terms of the growth turbidity method. In summary, these findings suggest that the PVA-M0.5-K0.1 sponge could be implemented to frustrate microbial infections and further ameliorate wound healing.
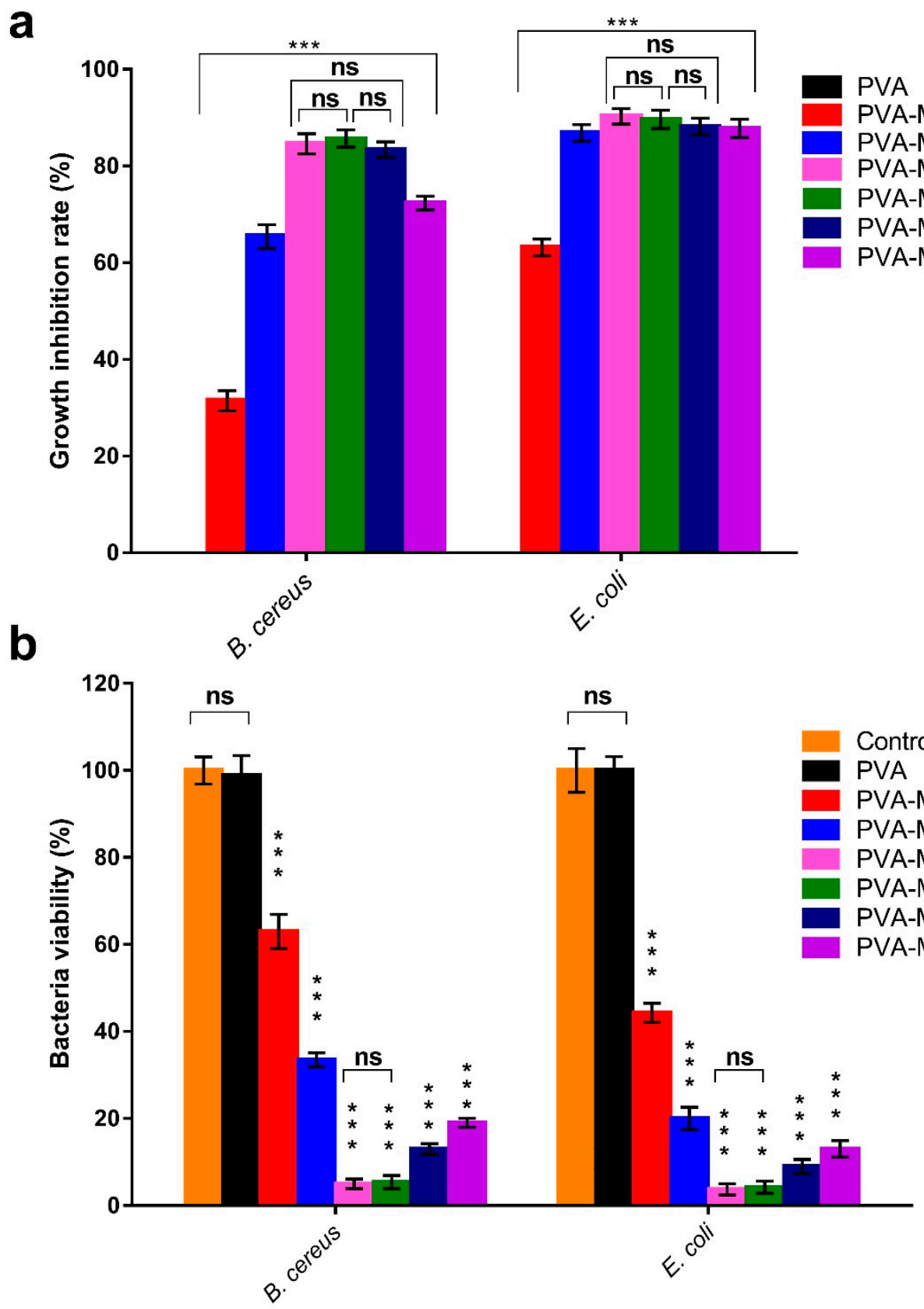

Figure 7. Antibacterial evaluations of PVA/marjoram and PVA/marjoram/kaolin composite sponges against $B$. cereus and E. coli compared to the pure PVA sponge adopting (a) growth turbidity method and (b) plate count method to determine the percentage of bacteria viability. Results are depicted as means $\pm \operatorname{SD}(n=5)\left({ }^{* * *} p<0.001\right.$, and (ns) points to non-significant difference). 


\subsection{Total Phenolic Content and Antioxidant Evaluation}

One of the detrimental bioburdens during wound healing is the overabundance of reactive oxygen species (ROS), provoking oxidative stress as a result of the phagocytosis mechanism $[39,46]$. This might incite lipid peroxidation, deactivation of vitals enzymes in addition to the damage of DNA, leading to impairment of wound healing and adjacent skin tissues [47]. Thus, the boost of wound dressing by antioxidant compounds is crucial to modulate the overabundance of ROS $[29,48]$.

A striking attribute of essential oils is their containing various phenolic compounds, which exclusively endow them with vital biological activities, such as antioxidant characteristics, in order to scavenge reactive oxygen species (ROS). In this regard, it has been reported that marjoram oil contains phenolic acids and terpenoids [21]. To explore the efficiency of PVA/marjoram and PVA/marjoram/kaolin sponges to release the marjoram oil into the surrounding medium represented by the phenolic compounds, the total phenolic contents were determined subsequent to immersing the tested sponges in ethanol. Accordingly, the entire sponges exploited their structural integrity and released the corresponding phenolic mixtures. As can be seen from Figure 8a, phenolic compounds were not detected for the pure PVA sponge, which served as a negative control. For the composite sponges, there is a clear trend of increasing the phenolic contents with the rise in the marjoram oil for PVA-M0.1, PVA-M0.25, and PVA-M0.5 groups. The incorporation of kaolin into the sponges altered the release profile of marjoram oil; however, no significant reduction in the release profile was found for the PVA-M0.5-K0.1 sponge compared with the PVA-M0.5 sponge.

On the other hand, in comparison with the PVA-M0.5 sponge, the release profiles of phenolic contents were significantly diminished for PVA-M0.5-K0.25 and PVA-M0.5-K0.5 sponges. This manner could be ascribed to the adsorption of marjoram oil on the surface of kaolin particles. Concurrently, it is worth mentioning that there were no statistically significant differences in the release profile of phenolic contents for PVA-M0.5-K0.25 and PVA-M0.5-K0.5 groups in relation to the PVA-M0.5-K0.1 group.

Figure $8 \mathrm{~b}$ displays the time-dependent decolorization of the $\mathrm{ABTS}^{\bullet+}$ cationic radical by ethanol extracts of PVA, PVA/marjoram and PVA/marjoram/kaolin sponges. It could be discerned that the PVA sponge (control) exhibited slight ABTS ${ }^{\bullet+}$ radical scavenging activity, which might be ascribed to the presence of hydroxyl groups along the PVA backbone. However, $\mathrm{ABTS}^{\bullet+}$ radical scavenging activity was significantly enhanced by adding marjoram oil to PVA/marjoram groups. Besides, the amalgamation of kaolin in terms of PVA/marjoram/kaolin groups reduced the $\mathrm{ABTS}^{\bullet+}$ radical scavenging capacity without a significant difference for PVA-M0.5-K0.1 compared to PVA-M0.5. Moreover, the statistical analyses demonstrated no significant differences in $\mathrm{ABTS}^{\bullet+}$ radical scavenging capacity for PVA-M0.5-K0.25 and PVA-M0.5-K0.5 sponges in relation to the PVA-M0.5K0.1 sponge. These results are in agreement with those obtained by measuring the total phenolic content in the previous section. Explicitly, the incidence of phenolic compounds in marjoram oil imparted an electron to $\mathrm{ABTS}^{\bullet+}$, which further decolorized and converted to a neutral form [49-51].

To further evince the antioxidant potency of PVA/marjoram and PVA/marjoram/kaolin groups, an in vitro design system has been applied to estimate the studied materials' capacity to eradicate free radicals based on DPPH assay. The mechanism of this assay depends on the scavenging of the stable free radical 1,1-diphenyl-2-picrylhydrazyl (DPPH) by reducing the DPPH violet color into yellow-colored diphenyl-picrylhydrazine as a consequence of accepting an electron from antioxidant compounds [52]. Figure $8 \mathrm{c}$ delineates the scavenging activity of the DPPH dye by PVA/marjoram and PVA/marjoram/kaolin sponges. The results are consistent with those presented in the $\mathrm{ABTS}^{\bullet+}$ assay. Furthermore, the pure PVA sponges showed a mild scavenging ratio of the DPPH dye on account of hydroxyl groups. At the same time, there are positive associations between the scavenging ratios of DPPH and the increase in marjoram oil contents. Moreover, the introduction of kaolin exposed no 
significant difference of DPPH scavenging for the entire PVA/marjoram/kaolin groups with regard to the PVA-M0.5 sponge.

Together, these results evidently indicate the potential application of PVA/marjoram/ kaolin sponges in wound healing, particularly the PVA-M0.5-K0.1 sponge, without any significant influence on the emancipation of phenolic compounds from marjoram oil.

a

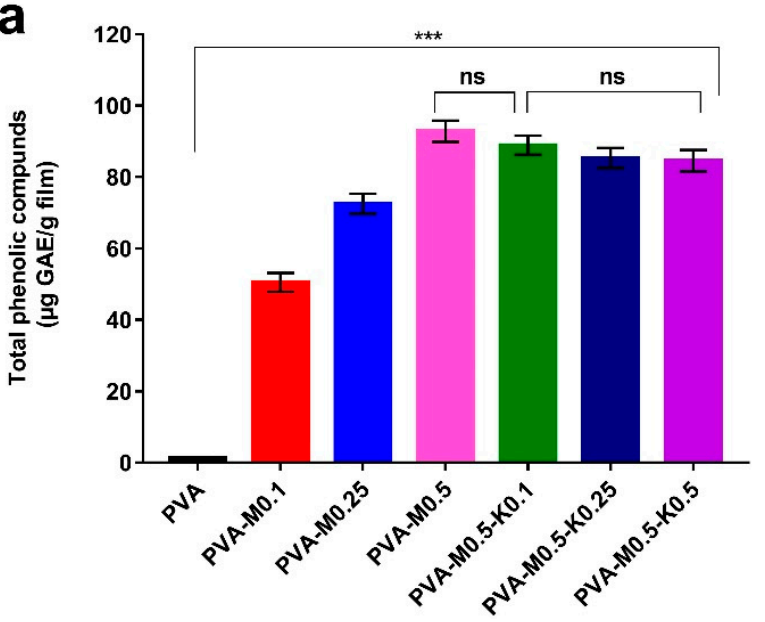

b

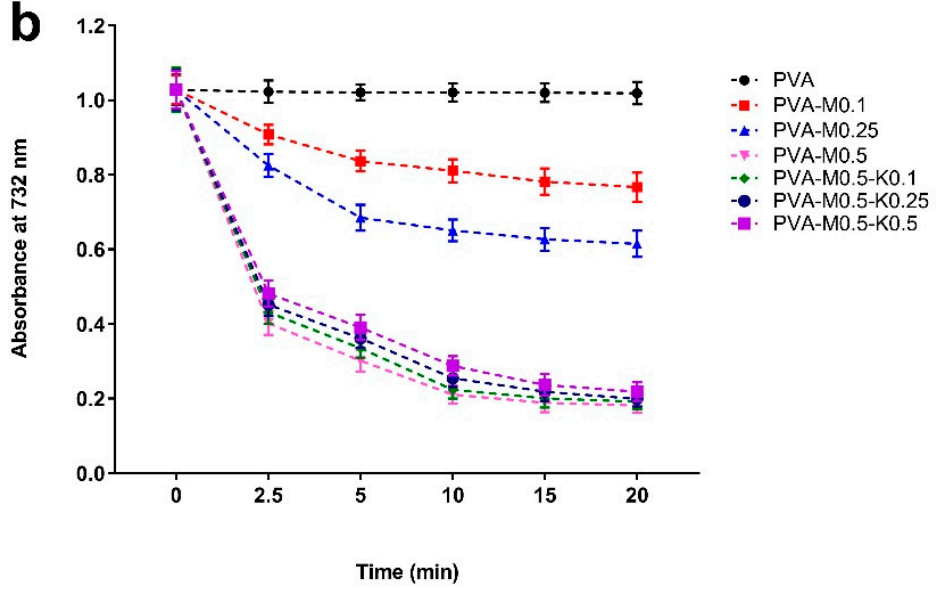

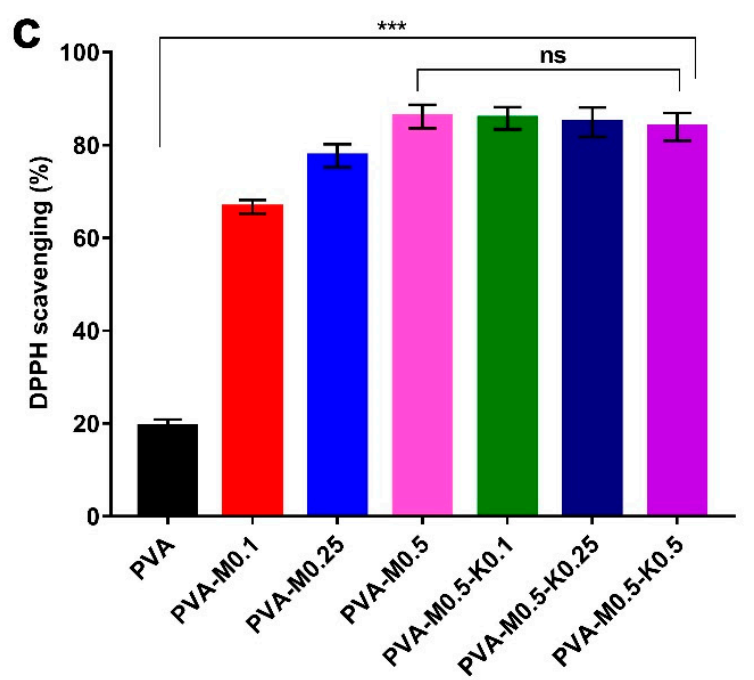

Figure 8. (a) Total phenolic compounds released from PVA/marjoram, and PVA/marjoram/kaolin composite sponges, (b) Time-dependent decolourization of $\mathrm{ABTS}^{\bullet+}$ dye by PVA/marjoram, and PVA/marjoram/kaolin composite sponges, and (c) Scavenging competency of DPPH free radical by PVA/marjoram, and PVA/marjoram/kaolin composite sponges. Results are presented as means $\pm \mathrm{SD}(n=5)\left({ }^{* * *} p<0.001\right.$, and (ns) points to a non-significant difference).

\subsection{Hemocompatibility, Thrombogenicity and Cytotoxicity Evaluations}

Hemocompatibility of biomaterials tailored to wound dressings, particularly hemostatic dressings, is an intrinsic property due to the unavoidable interactivity between blood and applied dressings [53,54]. The macroscopic photo in Figure 9a revealed the obvious variance in color between the seven sponge groups, the positive control (distilled water), and the negative control (PBS). Clearly, the entire sponge groups and the negative control emerged in yellow color without a significant difference. Conversely, the positive control tube appeared in red, implying the complete lysis of erythrocytes. The quantitative data of the hemolysis ratios for sponges PVA, PVA-M0.1, PVA-M0.25, PVA-M0.5, PVA-M0.5K0.1, PVA-M0.5-K0.25 and PVA-M0.5-K0.5 were $1.9 \%, 1.84 \%, 1.65 \%, 1.45 \%, 1.56 \%, 1.79 \%$, $1.98 \%$, respectively, as provided in Figure $9 \mathrm{~b}$. It could be extrapolated that the tested sponges showed non-hemolytic activities $(<2 \%)$ according to the American Society for 
Testing and Materials (ASTM F 756-00, 2000), implying the good hemocompatibility of the $\mathrm{PVA} / \mathrm{marjoram} /$ kaolin sponges.

The thrombogenicity test was conducted to appraise the PVA/marjoram/kaolin sponge groups' capacity to clot the blood, as illustrated in Figure 9c. Compared to the positive control, the thrombus formation was decreased for the PVA sponge; however, this diminution was not statistically significant. Therefore, this manner could be attributed to the hydrophilic trait of PVA. Nevertheless, it could be discovered that the introduction of marjoram oil substantially lessened thrombus formation. These results agree with those observed in prior studies [55,56], which elucidated this action by the presence of active phenolic compounds in marjoram oil, which hinder the aggregation of platelets. On the other hand, the supplementation of PVA/marjoram with different ratios of kaolin significantly escalated the weight of thrombus, which could be imputed to the influential blood clotting function of kaolin particles. Altogether, hemocompatibility and thrombogenicity findings suggest that PVA/marjoram/kaolin sponges could be significantly utilized as hemostatic wound dressings.

a
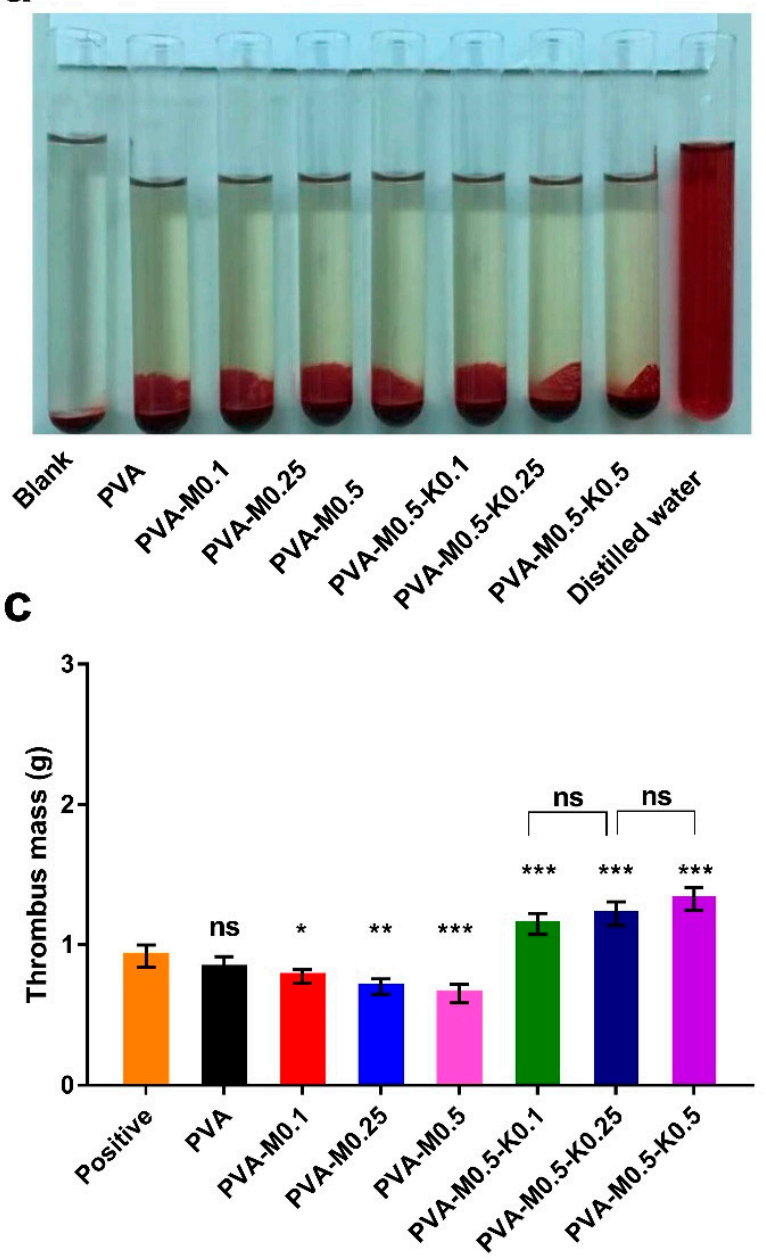

b

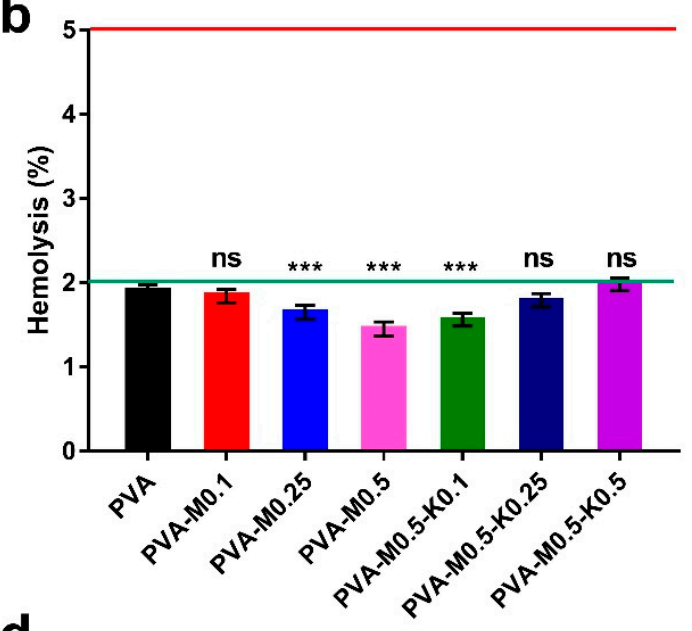

d

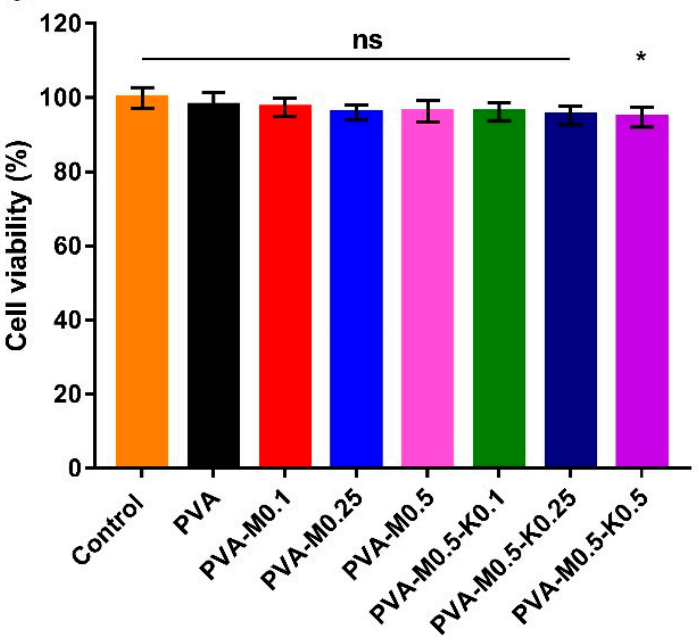

Figure 9. Photographs for the hemolysis test (a) and hemolytic percentages (b) reveal the hemocompatibility of PVA/marjoram and PVA/marjoram/kaolin composite sponges. (c) Thrombogenicity assessment for PVA/marjoram and PVA/marjoram/kaolin composite sponges demonstrate their capability to clot the blood through the formation of thrombus mass. (d) Cytotoxicity of PVA/marjoram and PVA/marjoram/kaolin composite sponges toward fibroblast cells show the safe behavior of the developed sponges. Results are presented as means $\pm \operatorname{SD}(n=6)\left(^{* * *} p<0.001\right.$, ${ }^{* *} p<0.01$, ${ }^{*} p<0.05$, and (ns) points to a non-significant difference). 
Cell compatibility test of wound dressings is crucial in order to assess the extent to which the fabricated sponges possess favorable biocompatibility in response to prevalent dermal cells, such as fibroblast, keratinocyte, and epithelial cells. During wound recovery, fibroblasts play a pivotal role in the construction of connective tissues, giving rise to the granulation of skin tissues and promoting skin remodeling [12,27,57]. Given this fact, alongside the cell interactions with wound dressings, we performed cytotoxicity investigations on fibroblast cells by the MTT assay. The cytotoxicity results exhibited no significant difference among the entire studied sponges, except for the sponge PVA-M0.5K0.5 compared to untreated cells, as illustrated in Figure 9d. Thus, the feasible application of PVA-M0.5-K0.1 and PVA-M0.5-K0.25 sponges in wound dressings can be deduced from these findings since they could sustain the dermal cells in healthy behavior for achieving their functions properly.

Overall, these salient results advocate future in vivo wound healing studies for the PVA-M0.5-K0.1 sponge composite as an antibacterial and hemostatic wound dressing.

\section{Materials and Methods}

\subsection{Materials and Bacterial Strains}

PVA (Mw = $72 \mathrm{kDa}$ ) was purchased from ACROS Organics ${ }^{\mathrm{TM}}$, Carlsbad, CA, USA. Chinese marjoram oil and absolute ethanol were provided from Sinopharm Chemical Reagent Co., Ltd. (Beijing, China). Kaolin (hydrated aluminium silicate), MTT 3-(4,5dimethylthiazol-2-yl)-2,5-diphenyltetrazolium bromide, sodium hydroxide, dimethyl sulfoxide (DMSO), and acid citrate dextrose solution (ACD) were obtained from SigmaAldrich (Chemie GmbH, Steinheim, Germany). Folin-Ciocalteu, gallic acid, 2,2-diphenyl-1picrylhydrazyl (DPPH) and 2,2'azino-bis(3-ethylbenzothiazoline-6-sulphonic acid, ABTS) were purchased from Sigma-Aldrich Co., Ltd., St. Louis, MO, USA. Dulbecco's Modified Eagle Medium (DMEM) and trypsin were purchased from Gibco (ThermoFisher Scientific, Waltham, MA, USA). Yeast extract, tryptone, and sodium chloride were received from Bioshop (Canada Inc., Ontario, CA, Canada).

Bacillus cereus (B. cereus) and Escherichia coli (E. coli), representing Gram-positive and Gram-negative bacteria, respectively, were used to study the antibacterial activities of the fabricated dressings. Prior to performing the antibacterial assay, the bacterial strains were refreshed via inoculating into $\mathrm{LB}$ medium containing g/L: $\mathrm{NaCl} 10 \mathrm{~g}$, peptone $10 \mathrm{~g}$, and yeast extract $5 \mathrm{~g}$, and then incubated at $37^{\circ} \mathrm{C}$ and $150 \mathrm{rpm}$ for $18 \mathrm{~h}$.

\subsection{Methodology}

\subsubsection{Preparation of Sponges}

$\mathrm{PVA} / \mathrm{marjoram} /$ kaolin sponge composites were fabricated adopting a freezing-thawing cycle approach in accordance with previously described procedures [58]. Briefly, mixtures of $5 \%(w / v)$ PVA, various concentrations of marjoram extract oil $(0.1,0.25$, and $0.5 \mathrm{~mL})$, and kaolin $(0.1,0.25$, and $0.5 \mathrm{~g})$ were thoroughly mixed prior to sonication and vortexing for $1 \mathrm{~h}$. After that, the blends were poured into Petri dishes, followed by five successive cycles of freezing at $-20{ }^{\circ} \mathrm{C}$ for $18 \mathrm{~h}$ and then thawing for $6 \mathrm{~h}$ at $25{ }^{\circ} \mathrm{C}$. The sponges with different volumes of marjoram $(0.1,0.25$, and $0.5 \mathrm{~mL})$ were designated as PVA-M0.1, PVA-M0.25, and PVA-M0.5, respectively, in addition to a control sponge of PVA. Moreover, the sponge PVA-M0.5 was supplemented with various kaolin contents $(0.1,0.25$, and $0.5 \mathrm{~g})$ and labelled as PVA-M0.5-K0.1, PVA-M0.5-K0.25, and PVA-M0.5-K0.5, respectively. The developed sponges were frozen in liquid nitrogen for $10 \mathrm{~min}$ and then lyophilized for further examinations.

\subsubsection{Characterization of the Sponges}

\section{FT-IR Analysis}

The alterations of the chemical structures of the designed sponges were investigated using a Fourier transform infrared spectrophotometer after thoroughly mixing a weight of 5 
mg of each sponge with potassium bromide (KBr). The FT-IR equipment (Shimadzu 8400S, Kyoto, Japan) was programmed to probe each sponge 40 times at a range of $400-4000 \mathrm{~cm}^{-1}$ for 40 scans.

\section{Morphological Examination and Thermal Analysis}

To scrutinize the formulated sponges' morphological variations, each sample was overlaid with a thin film of gold under vacuum conditions prior to surveying by scanning electron microscope (SEM, Joel Jsm 6360LA, Tokyo, Japan).

For thermal characterization, $\sim 5 \mathrm{mg}$ of each film in a sealed aluminium pan was analyzed employing a thermal gravimetric analyzer (TGA, Shimadzu $50 / 50 \mathrm{H}$, Kyoto, Japan) within a temperature range of $20-600{ }^{\circ} \mathrm{C}$ with a heating rate $\left(10^{\circ} \mathrm{C} / \mathrm{min}\right)$ and a nitrogen flow of $30 \mathrm{~mL} / \mathrm{min}$.

\section{Gel Fraction, Swelling Profile, In Vitro Degradation, and Porosity of Sponges}

For gel fraction determination, the sponges were placed in a vacuum oven for $24 \mathrm{~h}$ at $50{ }^{\circ} \mathrm{C}$ until dried and then weighed. Thereafter, the sponges were re-swollen for $24 \mathrm{~h}$ in distilled water until an equilibrium swelling point for eliminating soluble PVA was obtained. The sponges were subsequently dried in a vacuum oven at $50{ }^{\circ} \mathrm{C}$ and weighed [59]. The experiments were conducted in five replicates, and the gel fractions were estimated using Equation (1) as follows:

$$
\text { Gel fraction }(\%)=(\mathrm{We} / \mathrm{Wi}) \times 100
$$

where We and Wi refer to the weights of the dried sponge and swollen sponge, respectively.

The swelling capacities of sponges were appraised via the determination of their weights after immersing them into the water for time intervals. Approximately $1 \mathrm{~g}$ of a dried sponge was weighed and then dipped into $500 \mathrm{~mL}$ of distilled water. Dynamic Swelling was performed at $25{ }^{\circ} \mathrm{C}$ until reaching an equilibrium state. Each swollen sample was withdrawn at predetermined time points, and the water-adhered onto the surface was gently blotted using filter papers before weighing. Each experiment was replicated five times, and the swelling ratios were estimated using Equation (2) as follow:

$$
\text { Swelling ratio }(\%)=[(\mathrm{Ws}-\mathrm{Wd}) / \mathrm{Wd}] \times 100
$$

where (Ws) denotes the weight of the swollen sponge, while (Wd) refers to the weight of the sponge at the initial time.

To evaluate the porosity of the sponges, the measurements were performed following the procedure used by Yin et al. [60]. First, sponges were dried at $50^{\circ} \mathrm{C}$ for $2 \mathrm{~h}$ in a vacuum oven and then the dried weights were estimated. Next, the samples were plunged for $4 \mathrm{~h}$ in absolute ethanol. Subsequently, the swollen sponges were blotted to eliminate the extra ethanol using filter paper and then weighed. Finally, the porosity analyses were conducted in five replicates and calculated according to the Equation (3):

$$
\text { Porosity }(\%)=[(\mathrm{W} 2-\mathrm{W} 1) / \mathrm{pV}] \times 100
$$

where W1 and W2 refer to the weight of the sponge prior to and after being immersed in absolute ethanol, respectively, " $V$ " represents the volume of the sponge, and " $\mathrm{p}$ " denotes the density of absolute ethanol.

To perceive the hydrolytic degradation of the devised sponges, dried sponges were weighed, immersed into $3 \mathrm{~mL}$ PBS $(0.1 \mathrm{M}, \mathrm{pH} 7.4)$, and maintained at $37^{\circ} \mathrm{C}$. The sponges were then taken out at different time points and mildly wiped with soft papers to eliminate the excess water on the surface of sponges. Following this, the samples were dried under vacuum conditions and weighed. All experiments were conducted in five replicates. 


\subsubsection{Antibacterial Analysis}

The antibacterial evaluation of the prepared sponges was conducted adopting two approaches to determine optical densities and the colony-forming unit (CFU/mL). First, overnight bacterial cultures of B. cereus and E. coli were diluted in LB medium prior to adapting their turbidities were adapted following the McFarland 0.5 standard at $625 \mathrm{~nm}$ with $2 \times 10^{8} \mathrm{CFU} / \mathrm{mL}[61,62]$. Subsequently, $100 \mu \mathrm{L}$ of the diluted bacterial cultures were inoculated into $10 \mathrm{~mL}$ LB medium, including $50 \mathrm{mg}$ of tested sponges, before being incubated for $18 \mathrm{~h}$ at $37^{\circ} \mathrm{C}$ and $150 \mathrm{rpm}$. In contrast, the bacterial cultures without sponges were set out as controls. After incubation, the antibacterial capacity was estimated by two approaches; first by estimating the inhibition of bacterial growth employing a spectrophotometer at $600 \mathrm{~nm}$ and calculating the ratio of bacterial growth inhibition were determined using Equation (4):

$$
\text { Bacterial growth inhibition }(\%)=[(\mathrm{ODc}-\mathrm{ODi}) / \mathrm{ODc})] \times 100
$$

where ODc and ODi are the optical densities of bacterial cultures untreated and treated with a tested sponge, respectively.

For the second evaluation method, $50 \mu \mathrm{L}$ of bacterial cultures were spread over LB agar plates and then maintained for $24 \mathrm{~h}$ at $37^{\circ} \mathrm{C}$ before ascertaining the colony-forming unit $(\mathrm{CFU} / \mathrm{mL})$. Thus, both antibacterial tests were accomplished in five replicates.

\subsubsection{Total Phenolic Content}

The phenolic contents of the formulated films were assessed based on reducing the Folin-Ciocalteu reagent from yellow to blue colored compound. First, $50 \mathrm{mg}$ of each membrane was submerged into $5 \mathrm{~mL}$ of ethanol to extract the marjoram oil content in the membrane [63]. Afterwards, $0.5 \mathrm{~mL}$ of sponge supernatant was put into $2.0 \mathrm{~mL}$ of Folin-Ciocalteu reagent $(10 \%, v / v)$, followed by adding $2 \mathrm{~mL}$ sodium carbonate solution $(7.5 \%, w / v)$. The blend was maintained at $50{ }^{\circ} \mathrm{C}$ for $5 \mathrm{~min}$, and the absorption was then gauged at $760 \mathrm{~nm}$ by means of a spectrophotometer. The determinations were replicated five times and estimated in relation to the stranded curve for gallic acid solutions $(0-100 \mu \mathrm{g})$.

\subsubsection{Antioxidant Activity Determination}

\section{$\mathrm{ABTS}^{\bullet+}$ Radical Scavenging Assay}

For the ABTS radical scavenging assessment, the radical cations were prompted by the reaction of an aqueous solution of $\mathrm{K}_{2} \mathrm{~S}_{2} \mathrm{O}_{8}(3.30 \mathrm{mg})$ in water $(5 \mathrm{~mL})$ with ABTS $(17.2 \mathrm{mg})$. Then, the resultant bluish-green radical cation solution was kept overnight below $0{ }^{\circ} \mathrm{C}$ under dark conditions. Later, $1 \mathrm{~mL}$ of the solution was diluted to a final volume of $60 \mathrm{~mL}$ with distilled water and marked as the $\mathrm{ABTS}^{\bullet+}$ solution. The samples were extracted as presented above in the estimation of total phenolic content. Following this, $0.1 \mathrm{~mL}$ of each sponge leachate was put into $2.0 \mathrm{~mL}$ of $\mathrm{ABTS}^{\bullet+}$ solution. The $\mathrm{ABTS}^{\bullet+}$ evaluation was implemented five times, and the absorption was appraised at $730 \mathrm{~nm}$ at various time points.

\section{DPPH Radical Scavenging Activity}

The antioxidant properties of the sponge leachates were assessed by adapting the 2,2-diphenyl-1-picrylhydrazyl (DPPH) approach [43,64]. Accordingly, $6 \mathrm{mg}$ of DPPH were dissolved in $50 \mathrm{~mL}$ methanol $(0.3 \mathrm{mM})$, and then a volume of $2.5 \mathrm{~mL}$ of each sponge extract and $2.5 \mathrm{~mL}$ of the DPPH solution was thoroughly mixed. Next, the tube was incubated at room temperature for $20 \mathrm{~min}$ under dark conditions. Afterwards, the decolorization of the dye was quantified at $517 \mathrm{~nm}$ using a spectrophotometer. The reactions were replicated five times, and inhibition percentages of radicals were computed by the following Equation (5):

$$
\text { DPPH scavenging }(\%)=[(\mathrm{Ac}-\mathrm{As}) / \mathrm{Ac})] \times 100
$$


where Ac is the absorbance of the control DPPH solution and As is the absorbance of the sponge extract after reaction with the DPPH solution.

\subsubsection{Hemocompatibility of the Sponges}

In order to investigate the hemocompatibility of the formulated sponges, the hemolysis tests were executed as previously demonstrated with minor adaptations [65]. Anticoagulated blood was prepared for this determination by adding $1 \mathrm{~mL}$ of anticoagulant acid citrate dextrose solution (ACD) to $9 \mathrm{~mL}$ of blood. Prior to commencing the direct contact between blood and the tested membranes, about $1 \mathrm{~cm}^{2}$ of each film was plunged in phosphate buffer solution (PBS, pH 7.0) for $72 \mathrm{~h}$ at $37^{\circ} \mathrm{C}$. Following that, the PBS was poured out before immersing the sponges in $1 \mathrm{~mL}$ of ACD blood and keeping the tubes at $37^{\circ} \mathrm{C}$ for $3 \mathrm{~h}$. For preparing negative and positive control tubes, the equivalent volumes of the ACD blood were added to $7 \mathrm{~mL}$ of PBS and water, respectively. The tubes were carefully inverted three times every $30 \mathrm{~min}$ to preserve the appropriate contact of the films with the blood. Subsequently, each liquid was carefully moved to new tubes and clarified via centrifugation for $15 \mathrm{~min}$ at $200 \mathrm{rpm}$. The hemoglobin released by hemolysis was estimated at $540 \mathrm{~nm}$ employing a spectrophotometer (Model Ultrospec 2000). All determinations were implemented in five replicates, and the hemolysis ratio was computed using Equation (6):

$$
\text { Hemolysis }(\%)=[(\mathrm{ODm}-\mathrm{ODn}) /(\mathrm{ODp}-\mathrm{ODn})] \times 100
$$

where ODm is the absorbance value of a tested sponge, ODn is the absorbance value of the negative control, and ODp is the absorbance value of the positive control.

\subsubsection{Thrombogenicity Test}

A gravimetric method was applied, as described earlier, to ascertain the amounts of formed thrombus over the surface of the fabricated sponges [57]. ACD blood was prepared as demonstrated above. Membranes were plunged into PBS for $48 \mathrm{~h}$ at $37^{\circ} \mathrm{C}$. On completion of incubation time, the PBS was then poured out, and the ACD blood was positioned over the examined materials. At the same time, positive control was set out by applying the equivalent amount of ACD blood to an empty Petri dish.

For prompting the clotting reaction of blood, $20 \mu \mathrm{L}$ of a $10 \mathrm{M}$ calcium chloride solution was put onto the sponges. After $45 \mathrm{~min}$, the reactions were terminated by adding $5 \mathrm{~mL}$ $\mathrm{H}_{2} \mathrm{O}$. Subsequently, the clots were firmly attached with an additional $5 \mathrm{~mL}$ of a $36 \%$ formaldehyde solution and dried with tissue papers before weighing. Thrombogenicity examinations were repeated five times.

\subsubsection{Cytotoxicity Test of the Sponges}

The cellular toxicity of the membranes on NIH $3 \mathrm{~T} 3$ (mouse fibroblast cells) was appraised adopting MTT [3-(4,5-Dimethythiazol-2-yl)-2,5-Diphenyltetrazolium Bromide] method as demonstrated earlier with some adaptations $[66,67]$.

The NIH 3T3 cells were cultivated in Dulbecco's modified Eagle's medium (DMEM), dissolved in $10 \%$ fetal bovine serum and fostered at $5 \% \mathrm{CO}_{2}$ and $37{ }^{\circ} \mathrm{C}$ with a humidity of $85 \%$ in a $\mathrm{CO}_{2}$ incubator. Then, $0.5 \%$ trypsin was applied to detach the fibroblasts, and the cells were thereafter seeded at $5 \times 10^{3}$ cells/well in a 96-well plate. The plate was then incubated in the $\mathrm{CO}_{2}$ incubator as mentioned above for $24 \mathrm{~h}$.

Concurrently, $30 \mathrm{mg}$ of each sponge was sterilized by immersing in $70 \%$ ethanol, subjected to UV for $45 \mathrm{~min}$, and transferred into a 24-well plate containing $1 \mathrm{~mL}$ of DMEM at $37^{\circ} \mathrm{C}$ for $24 \mathrm{~h}$. Subsequently, the medium was discarded from the plate containing fibroblast cells and replaced with $100 \mu \mathrm{L}$ of the membrane's leach, while the control cells were supplied with $100 \mu \mathrm{L}$ of standard DMEM medium. After that, the 96-well plate was incubated for $24 \mathrm{~h}$ before washing the cells with PBS three times. Then, the MTT test was commenced by adding $20 \mu \mathrm{L}$ of MTT solution ( $5 \mathrm{mg} / \mathrm{mL}$ in serum-free medium) to each well, and the plate was then maintained in the $\mathrm{CO}_{2}$ incubator for $3 \mathrm{~h}$ at $37^{\circ} \mathrm{C}$. 
Subsequently, the MTT solution was replaced with $200 \mu \mathrm{L}$ of dimethylsulfoxide (DMSO) for each well. Finally, the plate was shaken at $100 \mathrm{rpm}$ for $5 \mathrm{~min}$, and the absorbance values were estimated at $570 \mathrm{~nm}$ by means of a microtiter plate reader. The investigation was carried out in six replicates for each sponge, and the viable ratio of fibroblast cells was evaluated following Equation (7):

$$
\text { Cell viability }(\%)=(\mathrm{Am} / \mathrm{Ac}) \times 100
$$

where $(\mathrm{Am})$ refers to the absorbance of cells doped with tested membrane, while (Ac) points to the absorbance of untreated cells.

\subsubsection{Statistical Analysis}

GraphPad Prism software (V. 5) was employed to analyze the statistical significance of the entire data. One-way and two-way analyses of variance (ANOVA) with Tukey's multiple comparison tests were thus applied. The entire determination values are expressed as means $\pm \mathrm{SD}$, and they were significantly considered at $p$-value $<0.05$, where $n=5$, except for the cytotoxicity studies $(n=6)$.

\section{Conclusions}

In summary, novel sponges based on PVA boosted by marjoram essential oil and kaolin were successfully designed to frustrate massive bleeding and bacterial infection, which could further accelerate full-thickness wound healing. PVA/marjoram $/$ kaolin sponges exhibited noticeable porous and lamellar structures. The amalgamation of marjoram and kaolin into PVA augmented the pore size of the devised sponges, thus encouraging cell attachment and proliferation. Moreover, they demonstrated great water absorption, which supports their competency to govern the hemorrhage quickly. PVA/marjoram $/$ kaolin sponges presented an outstanding performance in scavenging free radicals as antioxidant sponges and revealed high antibacterial activity in relation to pathogenic bacteria. Furthermore, manifested thrombogenicity, hemocompatibility, and cellular compatibility were corroborated for the developed sponges. Thus, the results clearly indicate the PVA-M0.5K0.1 sponge for future consideration as a hemostatic and antibacterial wound dressing. Therefore, future in vivo studies are justified to determine the extent of PVA-M0.5-K0.1 to enhance cutaneous wound restoration in cases of bleeding and microbial infections.

Author Contributions: T.M.T. and M.H.A. conceived the project; T.M.T., M.M.S. and M.H.A. conducted the experiments; T.M.T. and M.H.A. analyzed and interpreted the data, performed the statistical analyses, and designed the figures; T.M.T. and M.A.H. wrote the draft of the manuscript; T.M.T., M.H.A., A.M.O., T.H.A., M.S.M.-E. and M.H.A. revised the manuscript; T.M.T. and M.H.A. finalized the final version of the manuscript. All authors have read and agreed to the published version of the manuscript.

Funding: This research received no external funding.

Institutional Review Board Statement: Not applicable.

Informed Consent Statement: Informed consent was obtained from all subjects involved in the study.

Data Availability Statement: The datasets generated during the current study are available from the corresponding authors upon request.

Conflicts of Interest: The authors declare that they have no conflict of interest.

\section{References}

1. Berthet, M.; Gauthier, Y.; Lacroix, C.; Verrier, B.; Monge, C. Nanoparticle-Based Dressing: The Future of Wound Treatment? Trends Biotechnol. 2017, 35, 770-784. [CrossRef] [PubMed]

2. Tamer, T.M.; Valachová, K.; Hassan, M.A.; Omer, A.M.; El-Shafeey, M.; Eldin, M.S.M.; Šoltés, L. Chitosan/hyaluronan/edaravone membranes for anti-inflammatory wound dressing: In vitro and in vivo evaluation studies. Mater. Sci. Eng. C 2018, 90, 227-235. [CrossRef] 
3. Pereira, R.F.; Bártolo, P.J. Traditional Therapies for Skin Wound Healing. Adv. Wound Care (New Rochelle) 2016, 5, $208-229$. [CrossRef]

4. Gurtner, G.C.; Werner, S.; Barrandon, Y.; Longaker, M.T. Wound repair and regeneration. Nature 2008, 453, 314-321. [CrossRef]

5. King, D.R. Initial Care of the Severely Injured Patient. N. Engl. J. Med. 2019, 380, 763-770. [CrossRef] [PubMed]

6. $\quad$ Alarhayem, A.Q.; Myers, J.G.; Dent, D.; Liao, L.; Muir, M.; Mueller, D.; Nicholson, S.; Cestero, R.; Johnson, M.C.; Stewart, R.; et al. Time is the enemy: Mortality in trauma patients with hemorrhage from torso injury occurs long before the "golden hour". Am. J. Surg. 2016, 212, 1101-1105. [CrossRef] [PubMed]

7. Ma, Y.; Yao, J.; Liu, Q.; Han, T.; Zhao, J.; Ma, X.; Tong, Y.; Jin, G.; Qu, K.; Li, B.; et al. Liquid Bandage Harvests Robust Adhesive, Hemostatic, and Antibacterial Performances as a First-Aid Tissue Adhesive. Adv. Funct. Mater. 2020, 30, 2001820. [CrossRef]

8. Glick, J.B.; Kaur, R.R.; Siegel, D. Achieving hemostasis in dermatology-Part II: Topical hemostatic agents. Indian Dermatol. Online J. 2013, 4, 172-176. [PubMed]

9. Shefa, A.A.; Amirian, J.; Kang, H.J.; Bae, S.H.; Jung, H.-I.; Choi, H.-J.; Lee, S.Y.; Lee, B.-T. In vitro and in vivo evaluation of effectiveness of a novel TEMPO-oxidized cellulose nanofiber-silk fibroin scaffold in wound healing. Carbohydr. Polym. 2017, 177, 284-296. [CrossRef]

10. Zhao, X.; Guo, B.; Wu, H.; Liang, Y.; Ma, P.X. Injectable antibacterial conductive nanocomposite cryogels with rapid shape recovery for noncompressible hemorrhage and wound healing. Nat. Commun. 2018, 9, 2784. [CrossRef] [PubMed]

11. Liu, Y.; Xu, K.; Chang, Q.; Darabi, M.A.; Lin, B.; Zhong, W.; Xing, M. Highly Flexible and Resilient Elastin Hybrid Cryogels with Shape Memory, Injectability, Conductivity, and Magnetic Responsive Properties. Adv. Mater. 2016, 28, 7758-7767. [CrossRef] [PubMed]

12. Sultana, T.; Hossain, M.; Rahaman, S.; Kim, Y.S.; Gwon, J.-G.; Lee, B.-T. Multi-functional nanocellulose-chitosan dressing loaded with antibacterial lawsone for rapid hemostasis and cutaneous wound healing. Carbohydr. Polym. 2021, 272, 118482. [CrossRef] [PubMed]

13. Fang, H.; Wang, J.; Li, L.; Xu, L.; Wu, Y.; Wang, Y.; Fei, X.; Tian, J.; Li, Y. A novel high-strength poly(ionic liquid)/PVA hydrogel dressing for antibacterial applications. Chem. Eng. J. 2019, 365, 153-164. [CrossRef]

14. Qi, X.; Hu, X.; Wei, W.; Yu, H.; Li, J.; Zhang, J.; Dong, W. Investigation of Salecan/poly(vinyl alcohol) hydrogels prepared by freeze/thaw method. Carbohydr. Polym. 2015, 118, 60-69. [CrossRef] [PubMed]

15. Chen, Y.-N.; Peng, L.; Liu, T.; Wang, Y.; Shi, S.; Wang, H. Poly(vinyl alcohol)-Tannic Acid Hydrogels with Excellent Mechanical Properties and Shape Memory Behaviors. ACS Appl. Mater. Interfaces 2016, 8, 27199-27206. [CrossRef] [PubMed]

16. Awad, M.E.; López-Galindo, A.; Setti, M.; El-Rahmany, M.M.; Iborra, C.V. Kaolinite in pharmaceutics and biomedicine. Int. J. Pharm. 2017, 533, 34-48. [CrossRef] [PubMed]

17. Liang, Y.; Xu, C.; Li, G.; Liu, T.; Liang, J.F.; Wang, X. Graphene-kaolin composite sponge for rapid and riskless hemostasis. Colloids Surf. B Biointerfaces 2018, 169, 168-175. [CrossRef] [PubMed]

18. Hajlaoui, H.; Mighri, H.; Aouni, M.; Gharsallah, N.; Kadri, A. Chemical composition and in vitro evaluation of antioxidant, antimicrobial, cytotoxicity and anti-acetylcholinesterase properties of Tunisian Origanum majorana L. essential oil. Microb. Pathog. 2016, 95, 86-94. [CrossRef]

19. Arranz, E.; Jaime, L.; López de las Hazas, M.C.; Reglero, G.; Santoyo, S. Supercritical fluid extraction as an alternative process to obtain essential oils with anti-inflammatory properties from marjoram and sweet basil. Ind. Crop. Prod. 2015, 67, 121-129. [CrossRef]

20. Vági, E.; Simándi, B.; Suhajda, Á.; Héthelyi, É. Essential oil composition and antimicrobial activity of Origanum majorana L. extracts obtained with ethyl alcohol and supercritical carbon dioxide. Food Res. Int. 2005, 38, 51-57. [CrossRef]

21. Almasi, H.; Azizi, S.; Amjadi, S. Development and characterization of pectin films activated by nanoemulsion and Pickering emulsion stabilized marjoram (Origanum majorana L.) essential oil. Food Hydrocoll. 2020, 99, 105338. [CrossRef]

22. Tamer, T.M.; Sabet, M.M.; Omer, A.M.; Abbas, E.; Eid, A.I.; Mohy-Eldin, M.S.; Hassan, M.A. Hemostatic and antibacterial PVA/Kaolin composite sponges loaded with penicillin-streptomycin for wound dressing applications. Sci. Rep. 2021, 11, 3428. [CrossRef] [PubMed]

23. Aslam, M.; Kalyar, M.A.; Raza, Z.A. Polyvinyl alcohol: A review of research status and use of polyvinyl alcohol based nanocomposites. Polym. Eng. Sci. 2018, 58, 2119-2132. [CrossRef]

24. Mansur, H.S.; Oréfice, R.L.; Mansur, A.A.P. Characterization of poly(vinyl alcohol)/ poly(ethylene glycol) hydrogels and PVAderived hybrids by small-angle X-ray scattering and FTIR spectroscopy. Polymer 2004, 45, 7193-7202. [CrossRef]

25. Kamoun, E.A.; Kenawy, E.-R.S.; Tamer, T.M.; El-Meligy, M.A.; Eldin, M.S.M. Poly (vinyl alcohol)-alginate physically crosslinked hydrogel membranes for wound dressing applications: Characterization and bio-evaluation. Arab. J. Chem. 2015, 8, 38-47. [CrossRef]

26. Zhou, T.; Chen, S.; Ding, X.; Hu, Z.; Cen, L.; Zhang, X. Fabrication and Characterization of Collagen/PVA Dual-Layer Membranes for Periodontal Bone Regeneration. Front. Bioeng. Biotechnol. 2021, 9, 437. [CrossRef] [PubMed]

27. Fan, X.; Li, Y.; Li, N.; Wan, G.; Ali, M.A.; Tang, K. Rapid hemostatic chitosan/cellulose composite sponge by alkali/urea method for massive haemorrhage. Int. J. Biol. Macromol. 2020, 164, 2769-2778. [CrossRef]

28. Zhang, B.; He, J.; Shi, M.; Liang, Y.; Guo, B. Injectable self-healing supramolecular hydrogels with conductivity and photo-thermal antibacterial activity to enhance complete skin regeneration. Chem. Eng. J. 2020, 400, 125994. [CrossRef] 
29. Wang, X.; Qi, J.; Zhang, W.; Pu, Y.; Yang, R.; Wang, P.; Liu, S.; Tan, X.; Chi, B. 3D-printed antioxidant antibacterial carboxymethyl cellulose/ E-polylysine hydrogel promoted skin wound repair. Int. J. Biol. Macromol. 2021, 187, 91-104. [CrossRef]

30. Dong, R.; Zhao, X.; Guo, B.; Ma, P.X. Self-Healing Conductive Injectable Hydrogels with Antibacterial Activity as Cell Delivery Carrier for Cardiac Cell Therapy. ACS Appl. Mater. Interfaces 2016, 8, 17138-17150. [CrossRef]

31. Qu, J.; Zhao, X.; Liang, Y.; Xu, Y.; Ma, P.X.; Guo, B. Degradable conductive injectable hydrogels as novel antibacterial, anti-oxidant wound dressings for wound healing. Chem. Eng. J. 2019, 362, 548-560. [CrossRef]

32. Tan, H.B.; Wang, F.Y.; Ding, W.; Zhang, Y.; Ding, J.; Cai, D.X.; Yu, K.F.; Yang, J.; Yang, L.; Xu, Y.Q. Fabrication and Evaluation of Porous Keratin/chitosan (KCS) Scaffolds for Effectively Accelerating Wound Healing. Biomed. Environ. Sci. 2015, 28, 178-189. [PubMed]

33. Sung, J.H.; Hwang, M.-R.; Kim, J.O.; Lee, J.H.; Kim, Y.I.; Kim, J.H.; Chang, S.W.; Jin, S.G.; Kim, J.A.; Lyoo, W.S.; et al. Gel characterisation and in vivo evaluation of minocycline-loaded wound dressing with enhanced wound healing using polyvinyl alcohol and chitosan. Int. J. Pharm. 2010, 392, 232-240. [CrossRef] [PubMed]

34. Adeli-Sardou, M.; Yaghoobi, M.M.; Torkzadeh-Mahani, M.; Dodel, M. Controlled release of lawsone from polycaprolactone/gelatin electrospun nano fibers for skin tissue regeneration. Int. J. Biol. Macromol. 2019, 124, 478-491. [CrossRef] [PubMed]

35. He, J.; Shi, M.; Liang, Y.; Guo, B. Conductive adhesive self-healing nanocomposite hydrogel wound dressing for photothermal therapy of infected full-thickness skin wounds. Chem. Eng. J. 2020, 394, 124888. [CrossRef]

36. Landsman, T.L.; Touchet, T.; Hasan, S.M.; Smith, C.; Russell, B.; Rivera, J.; Maitland, D.J.; Cosgriff-Hernandez, E. A shape memory foam composite with enhanced fluid uptake and bactericidal properties as a hemostatic agent. Acta Biomater. 2017, 47, 91-99. [CrossRef]

37. Ruiz-Navajas, Y.; Viuda-Martos, M.; Sendra, E.; Perez-Alvarez, J.A.; Fernández-López, J. In vitro antibacterial and antioxidant properties of chitosan edible films incorporated with Thymus moroderi or Thymus piperella essential oils. Food Control. 2013, 30, 386-392. [CrossRef]

38. Zhou, M.; Lin, F.; Li, W.; Shi, L.; Li, Y.; Shan, G. Development of nanosilver doped carboxymethyl chitosan-polyamideamine alginate composite dressing for wound treatment. Int. J. Biol. Macromol. 2021, 166, 1335-1351. [CrossRef]

39. He, J.; Liang, Y.; Shi, M.; Guo, B. Anti-oxidant electroactive and antibacterial nanofibrous wound dressings based on poly( $\varepsilon$ caprolactone)/quaternized chitosan-graft-polyaniline for full-thickness skin wound healing. Chem. Eng. J. 2020, $385,123464$. [CrossRef]

40. Liu, X.; You, L.; Tarafder, S.; Zou, L.; Fang, Z.; Chen, J.; Lee, C.H.; Zhang, Q. Curcumin-releasing chitosan/aloe membrane for skin regeneration. Chem. Eng. J. 2019, 359, 1111-1119. [CrossRef]

41. Omer, A.M.; Ziora, Z.M.; Tamer, T.M.; Khalifa, R.E.; Hassan, M.A.; Mohy-Eldin, M.S.; Blaskovich, M.A.T. Formulation of Quaternized Aminated Chitosan Nanoparticles for Efficient Encapsulation and Slow Release of Curcumin. Molecules 2021, 26, 449. [CrossRef] [PubMed]

42. Ninan, N.; Muthiah, M.; Park, I.-K.; Elain, A.; Thomas, S.; Grohens, Y. Pectin/carboxymethyl cellulose/microfibrillated cellulose composite scaffolds for tissue engineering. Carbohydr. Polym. 2013, 98, 877-885. [CrossRef]

43. Hassan, M.A.; Tamer, T.M.; Valachová, K.; Omer, A.M.; El-Shafeey, M.; Mohy Eldin, M.S.; Šoltés, L. Antioxidant and antibacterial polyelectrolyte wound dressing based on chitosan/hyaluronan/phosphatidylcholine dihydroquercetin. Int. J. Biol. Macromol. 2021, 166, 18-31. [CrossRef]

44. Liang, Y.; Zhao, X.; Hu, T.; Chen, B.; Yin, Z.; Ma, P.X.; Guo, B. Adhesive Hemostatic Conducting Injectable Composite Hydrogels with Sustained Drug Release and Photothermal Antibacterial Activity to Promote Full-Thickness Skin Regeneration During Wound Healing. Small (Weinh. der Bergstr. Ger.) 2019, 15, e1900046. [CrossRef] [PubMed]

45. Tamer, T.M.; Hassan, M.A.; Omer, A.M.; Baset, W.M.A.; Hassan, M.E.; El-Shafeey, M.E.A.; Eldin, M.S.M. Synthesis, characterization and antimicrobial evaluation of two aromatic chitosan Schiff base derivatives. Process. Biochem. 2016, 51, 1721-1730. [CrossRef]

46. Dunnill, C.; Patton, T.; Brennan, J.; Barrett, J.; Dryden, M.; Cooke, J.; Leaper, D.; Georgopoulos, N.T. Reactive oxygen species (ROS) and wound healing: The functional role of ROS and emerging ROS-modulating technologies for augmentation of the healing process. Int. Wound J. 2017, 14, 89-96. [CrossRef] [PubMed]

47. Akbik, D.; Ghadiri, M.; Chrzanowski, W.; Rohanizadeh, R. Curcumin as a wound healing agent. Life Sci. 2014, 116, 1-7. [CrossRef]

48. Qu, J.; Zhao, X.; Liang, Y.; Zhang, T.; Ma, P.X.; Guo, B. Antibacterial adhesive injectable hydrogels with rapid self-healing, extensibility and compressibility as wound dressing for joints skin wound healing. Biomaterials 2018, 183, 185-199. [CrossRef] [PubMed]

49. Moteriya, P.; Padalia, H.; Chanda, S. Characterization, synergistic antibacterial and free radical scavenging efficacy of silver nanoparticles synthesized using Cassia roxburghii leaf extract. J. Genet. Eng. Biotechnol. 2017, 15, 505-513. [CrossRef] [PubMed]

50. Tamer, T.M.; Valachová, K.; Mohyeldin, M.S.; Soltes, L. Free radical scavenger activity of chitosan and its aminated derivative. J. Appl. Pharm. Sci. 2016, 6, 195-201. [CrossRef]

51. Abdelrazik, T.M.; Valachová, K.; Mohyeldin, M.S.; Soltes, L. Free radical scavenger activity of cinnamyl chitosan schiff base. J. Appl. Pharm. Sci. 2016, 6, 130-136. [CrossRef]

52. Gharibi, R.; Yeganeh, H.; Rezapour-Lactoee, A.; Hassan, Z.M. Stimulation of Wound Healing by Electroactive, Antibacterial, and Antioxidant Polyurethane/Siloxane Dressing Membranes: In Vitro and in Vivo Evaluations. ACS Appl. Mater. Interfaces 2015, 7, 24296-24311. [CrossRef] [PubMed] 
53. Mao, L.; Hu, S.; Gao, Y.; Wang, L.; Zhao, W.; Fu, L.; Cheng, H.; Xia, L.; Xie, S.; Ye, W.; et al. Biodegradable and Electroactive Regenerated Bacterial Cellulose/MXene (Ti3C2Tx) Composite Hydrogel as Wound Dressing for Accelerating Skin Wound Healing under Electrical Stimulation. Adv. Healthc. Mater. 2020, 9, 2000872. [CrossRef] [PubMed]

54. Tamer, T.M.; Collins, M.N.; Valachová, K.; Hassan, M.A.; Omer, A.M.; Mohy-Eldin, M.S.; Švík, K.; Jurčík, R.; Ondruška, L.; Biró, C.; et al. MitoQ Loaded Chitosan-Hyaluronan Composite Membranes for Wound Healing. Materials 2018, 11, 569. [CrossRef] [PubMed]

55. Yazdanparast, R.; Shahriyary, L. Comparative effects of Artemisia dracunculus, Satureja hortensis and Origanum majorana on inhibition of blood platelet adhesion, aggregation and secretion. Vasc. Pharmacol. 2008, 48, 32-37. [CrossRef]

56. Okazaki, K.; Nakayama, S.; Kawazoe, K.; Takaishi, Y. Antiaggregant effects on human platelets of culinary herbs. Phytother. Res. 1998, 12, 603-605. [CrossRef]

57. Tamer, T.M.; Hassan, M.A.; Valachová, K.; Omer, A.M.; El-Shafeey, M.E.A.; Mohy Eldin, M.S.; Šoltés, L. Enhancement of wound healing by chitosan/hyaluronan polyelectrolyte membrane loaded with glutathione: In vitro and in vivo evaluations. J. Biotechnol. 2020, 310, 103-113. [CrossRef]

58. Peppas, N.A.; Stauffer, S.R. Reinforced uncrosslinked poly (vinyl alcohol) gels produced by cyclic freezing-thawing processes: A short review. J. Control. Release 1991, 16, 305-310. [CrossRef]

59. Yang, X.; Liu, Q.; Chen, X.; Yu, F.; Zhu, Z. Investigation of PVA/ws-chitosan hydrogels prepared by combined $\gamma$-irradiation and freeze-thawing. Carbohydr. Polym. 2008, 73, 401-408. [CrossRef]

60. Yin, L.; Fei, L.; Tang, C.; Yin, C. Synthesis, characterization, mechanical properties and biocompatibility of interpenetrating polymer network-super-porous hydrogel containing sodium alginate. Polym. Int. 2007, 56, 1563-1571. [CrossRef]

61. Hassan, M.A.; Tamer, T.M.; Rageh, A.A.; Abou-Zeid, A.M.; Abd El-Zaher, E.H.F.; Kenawy, E.-R. Insight into multidrug-resistant microorganisms from microbial infected diabetic foot ulcers. Diabetes Metab. Syndr. Clin. Res. Rev. 2019, 13, 1261-1270. [CrossRef] [PubMed]

62. Hassan, M.A.; Omer, A.M.; Abbas, E.; Baset, W.M.A.; Tamer, T.M. Preparation, physicochemical characterization and antimicrobial activities of novel two phenolic chitosan Schiff base derivatives. Sci. Rep. 2018, 8, 11416. [CrossRef] [PubMed]

63. El Fawal, G.F.; Omer, A.M.; Tamer, T.M. Evaluation of antimicrobial and antioxidant activities for cellulose acetate films incorporated with Rosemary and Aloe Vera essential oils. J. Food Sci. Technol. 2019, 56, 1510-1518. [CrossRef] [PubMed]

64. Tamer, T.M.; Hassan, M.A.; Omer, A.M.; Valachová, K.; Eldin, M.S.M.; Collins, M.N.; Šoltés, L. Antibacterial and antioxidative activity of O-amine functionalized chitosan. Carbohydr. Polym. 2017, 169, 441-450. [CrossRef] [PubMed]

65. Hassan, M.A.; Amara, A.A.; Haroun, B.M. Leucocytes show improvement growth on PHA polymer surface. Pak. J. Pharm. Sci. 2010, 23, 332-336. [PubMed]

66. Mosmann, T. Rapid colorimetric assay for cellular growth and survival: Application to proliferation and cytotoxicity assays. J. Immunol. Methods 1983, 65, 55-63. [CrossRef]

67. El-Fakharany, E.; Hassan, M.; Taha, T. Production and application of extracellular laccase produced by Fusarium oxysporum EMT. Int. J. Agric. Biol. 2016, 18, 939-947. [CrossRef] 